\title{
Continuiteit en perspectief van het Nederlandse koningschap
}

\author{
Ernst Hirsch Ballin*
}

I Inleiding

\section{I.I De constitutie tussen ontstaansgeschiedenis en verwachtingen voor de toekomst}

Wanneer koningin Beatrix het moment gekomen acht afstand te doen van 'de Kroon van het Koninkrijk' en in de lijn der erfopvolging haar oudste zoon Willem-Alexander als koning wordt 'ingehuldigd in de hoofdstad Amsterdam', zullen de burgers, vertegenwoordigd in de verenigde vergadering der Staten-Generaal, zich wellicht afvragen of hier een magische traditie wordt voltrokken, dan wel een moderne democratie haar symboliek in ere houdt.

Het een sluit het ander niet uit. Het koningschap geniet volop politieke belangstelling en is onderwerp geworden van een - inmiddels in sommige media dramatisch versimpeld - politiek debat. De bekende radio- en internetdiscussierubriek Stand.nl presenteerde bijvoorbeeld op 26 augustus 201 I onder meer de volgende vragen: 'Is de modernisering van het koningschap een goed idee? Of kunnen we de koninklijke inbreng in de politiek niet missen?' De vraag veronderstelt dus dat er een - met modernisering conflicterende - koninklijke inbreng in de politiek is. In dit preadvies zijn de logischerwijs voorafgaande vragen aan de orde, namelijk van welke aard de koninklijke 'inbreng' in het staatsbestel is, en als die niet zelf van politieke aard is, hoe deze zich dan wél tot de politiek verhoudt.

Een zinvolle beoordeling van de constitutionele positie van de Koning vergt meer dan standpunten. Ze moet het koningschap plaatsen in de context van de Nederlandse en Europese aspiraties van een democratische en rechtsstatelijke constitutie en de specifieke Nederlandse historie waarin aan die aspiraties vorm is gegeven. Ik zal geen pogingen doen de talloze staatsrechtelijke beschouwingen over het Nederlandse koningschap van de afgelopen bijna twee eeuwen samen te vatten. Nog

* Prof. dr. Ernst M.H. Hirsch Ballin is hoogleraar Nederlands en Europees constitutioneel recht, Tilburg University Law School. De auteur dankt Wessel Wijtvliet, student-assistent bij het Department Public Law, Jurisprudence and Legal History van Tilburg University, voor zijn ondersteuning bij de voorbereiding van dit preadvies.

I Aldus de bewoordingen van artikel I van het Statuut voor het Koninkrijk der Nederlanden.

2 Artikel 32 van de Grondwet voor het Koninkrijk der Nederlanden. 
onlangs verscheen een boekje met een boeiende historisch-juridische synthese van de hand van Fasseur. ${ }^{3}$ Eerder in 2010 verscheen een staatsrechtelijk onderbouwde nota van de minister-president waarin wordt geconcludeerd dat de grondwetsbepalingen over het koningschap geen wijziging behoeven. Naar de argumentatie in die nota zal ik op enkele plaatsen verwijzen. Ook zal ik enige aandacht besteden aan een recent advies van een PvdA-commissie 4 en de begin september aanhangig gemaakte drie initiatiefvoorstellen van de PVV-Kamerleden Elissen en Helder tot wijziging van de bepalingen in het Statuut voor het Koninkrijk der Nederlanden en de Grondwet inzake het koningschap. ${ }^{5}$

Geen van deze twee (onderling uiteenlopende) recente politieke standpunten komt voort uit principiële bezwaren tegen erfelijke ambten. De PvdA-commissie meent 'dat alleen indien volstrekt onvermijdelijk, een pleidooi zou moeten worden gevoerd voor herziening van de Grondwet'; 'ernstige problemen' ziet zij echter niet. ${ }^{6} \mathrm{Zij}$ doet wel een voorstel voor grondwetswijziging ten aanzien van het voorzitterschap van de Raad van State, maar urgent is dat niet: 'als zich daartoe de gelegenheid voordoet'. Daarentegen strekken de PVV-voorstellen ertoe, de Koning door een reeks ingrijpende wijzigingen louter 'een representatieve en ceremoniële rol als staatshoofd toe te kennen'. ${ }^{8}$ De bezwaren tegen de huidige situatie die in de recente politieke discussie naar voren komen, betreffen de veronderstelde macht van de Koning in politieke zin. De discussie hierover is echter belast door beelden uit het verleden over min of meer het gehele staatsbestel dominerende koninklijke macht, waarvan nog steeds resten aanwezig zouden zijn. Daarbij wordt er echter aan voorbij gezien dat, met behoud van historische vormen, het koningschap als de constitutionele institutie een fundamenteel andere betekenis heeft gekregen.

Dit is een van de vele voorbeelden van vernieuwing van het constitutionele recht met behoud van oude vormen. Zoals Van der Hoeven in 1958 in zijn dissertatie heeft laten zien, leiden veranderingen in de ethische, godsdienstige en politieke waarderingspatronen ertoe dat bestaande instituties met behoud van verschijningsvormen in andere verhoudingen tot elkaar komen te staan. ${ }^{9}$ Met Seyla Benhabib zou men dit, in het voetspoor van Jacques Derrida, iterations kunnen noemen, waardoor de betekenis van een begrip verandert telkens wanneer men zich er wederom van bedient; het heeft geen zin, daar een beroep op de 'oorspronkelijke betekenis' van het begrip tegenover te stellen. ${ }^{\text {Io }}$

C. Fasseur, De gekroonde republiek, Amsterdam: Balans $201 \mathrm{I}$.

4 Verbindend koningschap in de Republiek. Advies van de commissie ad hoc 'Actualisatie toekomst Koningshuis' van de Partij van de Arbeid. Amsterdam, 24 augustus 201 .

Kamerstukken II 20I0/II, 32865 (RI957), nrs. I-3, 32866 (RI958), nrs. I-3, en 32 867, nrs. I-3.

P. 3 .

P. 9 .

Zie de drie memories van toelichting.

J. van der Hoeven, De plaats van de grondwet in het constitutionele recht (diss. Amsterdam UvA),

Zwolle: W.E.J. Tjeenk Willink 1958; aangevulde heruitgave ibidem I988.

Io S. Benhabib, Another Cosmopolitanism, Oxford: Oxford University Press 2006, pp. 47-48. 
Dit geldt ook voor het koningschap, dat sedert de stichting van het Koninkrijk der Nederlanden, nu bijna twee eeuwen geleden, onderhevig was aan iterations in de zich ontwikkelende context van de democratische rechtsstaat. In dit proces van voortdurende herbepaling van context en betekenis waren er telkens weer momenten waarop de ontwikkeling in de ene of de andere richting kon gaan. Welke richting werd ingeslagen, hing af van degenen die op dat moment hun eigen positie (en daarmee soms hun plaats in de geschiedenis) bepaalden, zoals koning Willem II, die in I848 tegen zijn eigen familie inging en 'in één nacht van conservatief liberaal' geworden de meest significante grondwetsherziening van onze constitutionele geschiedenis aanvaardde. ${ }^{\text {II }}$

In het huidige tijdsgewricht kan het koningschap, wanneer het niet tot ceremonieel wordt gereduceerd, een betekenisvolle rol vervullen juist als het niet in politieke zin wordt begrepen; ik zal dit verderop toelichten. Daarom zie ik geen heil in de eerder genoemde voorstellen voor grondwetswijziging en evenmin voor de door anderen bepleite overgang naar een zuiver republikeinse staatsvorm. ${ }^{12}$ Dit neemt niet weg dat deze en andere, wellicht theoretisch eenvoudiger vormen van inrichting van het democratisch-rechtsstatelijk constitutioneel bestel denkbaar zijn. Een andere historie had tot andere resultaten geleid en kan dat in de toekomst alsnog doen. Beslissend was en is echter hoe de betrokkenen - koning, ministers, parlementsleden, andere ambtsdragers, burgers - zich nu en in de toekomst tot de constitutie verhouden, en dat begint met begrip van de historisch gevormde constitutionele verhoudingen. ${ }^{13}$ Dit geldt ook voor de plaats van het koningschap in het constitutionele recht. Daaraan wil dit preadvies een bijdrage leveren.

Hierbij moet een verband worden gelegd met staatstheoretische concepten. Men beschrijft het Nederlandse staatsbestel vaak als een 'constitutionele monarchie', in tegenstelling tot de absolute monarchieën van het ancien régime. Deze kwalificatie is niet onjuist, maar zegt weinig; dat blijkt al uit het feit dat ze ook kon worden gebezigd ten aanzien van het staatsbestel anno I8I4. In de negentiende en de twintigste eeuw hebben sociaal-cultureel met Nederland vergelijkbare Europese staten zich ontwikkeld tot democratieën, d.w.z. staten waarin de staatsmacht niet door de soevereiniteit van de vorst, maar door betrokkenheid en uitspraken van de burgers ( $\delta$ ' $\mu$ os, 'volk', is het oud-Griekse woord voor het geheel van de vrije burgers) wordt gelegitimeerd. Het beginsel van democratie houdt in Seyla Benhabibs (inderdaad principiële) omschrijving in 'that the people are not only the object but also the authors of the law to which they are subject'. ${ }^{14}$

II Fasseur, o.c., p. 47; Van der Hoeven, aanvullend hoofdstuk in o.c., p. 297.

I2 Zie L. Prakke en A.J. Nieuwenhuis (red.), Monarchie en Republiek (Publicaties van de Staatsrechtkring, deel I8), Zwolle: W.E.J. Tjeenk Willink 2000; H.U. Jessurun d'Oliveira, M.H. Klijnsma, J.H. Reestman, P. Vinken en W. Voermans, Grondwet van de Republiek Nederland. Drie modellen, Amsterdam: Prometheus 2004.

I3 Vgl. Fasseur, o.c., p. Io6.

I4 O.c., p. I48. 
Behoudens elementen van directe democratie hebben democratische staten de vorm aangenomen van parlementaire en presidentiële democratieën, in allerlei varianten. Een 'monarchale democratie' - als zoiets al bestaat: wellicht heeft Jordanië daar iets van weg - is Nederland zeker niet, wel sedert de tweede helft van de negentiende eeuw een parlementaire democratie. Het kost kennelijk moeite om te begrijpen dat de erfelijkheid van het koningschap zich in Nederland heeft verbonden met een door en door parlementair-democratische staatsvorm. Hierbij komt wellicht de angst dat het begrip 'monarchie' zal worden opgevat als een indicatie van een democratisch tekort. Dit maakt het begrijpelijk dat het koningschap in Nederland regelmatig wordt verklaard als 'eigenlijk' republikeins, al vanaf het moment dat Willem van Oranje de leiding nam in de opstand tegen de Habsburgse monarchie. ${ }^{15}$

Het Nederlands constitutionele bestel is dus dat van een parlementaire democratie met erfelijk staatshoofd. Het lijkt overbodig nog toe te voegen dat deze staatsvorm een constitutionele democratie is, maar de toevoeging van de rechtsstatelijkheid als kenmerk is niet overbodig. Een democratische rechtsstaat bindt óók meerderheidsuitspraken aan constitutionele normen die minderheden beschermen. Zulke eisen beletten, bij meerderheid van stemmen af te doen aan de gelijke rechten van alle burgers zonder onderscheid.

In tijden van osmose van mediamacht en populisme is het echter wél van belang, te onderstrepen dat een democratische rechtsstaat niet tot democratisch absolutisme mag leiden: een risico dat zich blijkens een fenomeen als het berlusconisme ${ }^{\mathrm{I} 6}$ en de schending van het folterverbod in de Amerikaanse war on terror ook in vitale democratieën kan voordoen. Dit is de reden waarom een constitutionele democratie altijd tegenwichten moet omvatten tegen een verabsolutering van het democratisch meerderheidsprincipe. Deze tegenwichten omvatten normatieve kaders waarvan zelfs bij twee derde meerderheid niet mag worden afgeweken (zoals de in rechtstreeks werkende verdragsbepalingen neergelegde grondrechten, onafhankelijke rechtspraak ook als de politiek daar 'last' van heeft, en niet-politieke instituties die het politieke proces aan de procedures van de democratische rechtsstaat houden). In een parlementaire democratie behoort het staatshoofd bij uitstek tot de instituties van de laatste soort; in een presidentiële democratie is dat niet op dezelfde manier doenlijk, maar juist dit verklaart dat bijvoorbeeld in het Amerikaanse presidentiele regeringssysteem de president een zeer sterke positie van het Congres en het Supreme Court tegenover zich vindt. Presidentiële stelsels zonder zulke tegenwichten

I5 Soms, bijvoorbeeld in het aangehaalde werkje van Fasseur, wordt gewezen op de republikeinse kenmerken die de Nederlandse staatsvorm ook na de instelling van het koningschap heeft behouden.

I6 'Berlusconismo è un neologismo della lingua italiana, che interviene solitamente nel linguaggio del giornalismo e della sociologia politica per indicare le linee guida e i valori che ispirano l'azione politica di Silvio Berlusconi, e il suo modo di porsi nei confronti dell'opinione pubblica', aldus Wikipedia Italiana s.v. Berlusconismo, www.it.wikipedia.org/wiki/Berlusconismo\#cite_ note-o, zoals geraadpleegd op 26 augustus 20Ir. Zie G. La Grassa en C. Preve, Il teatro dell'assurdo. Cronaca estoria dei recenti avvenimenti italiani. Una critica alla cultura dominante della sinistra nell'attuale scontro tra berlusconismo e progressismo, Milano: Punto Rosso 1995. 
(met gekozen 'leiders van de natie', en dergelijke) houden, naar de ervaring leert, snel op, democratieën te zijn.

De hand- en leerboeken over het Nederlandse staatsrecht beschrijven gebruikelijkerwijs, welke grondwetsbepalingen het koningschap definiëren en onderwerpen zoals de erfopvolging regelen. Ze zouden ons kunnen doen geloven dat we een Koningin hebben, of straks een Koning, omdat de Grondwet zulks bepaalt. Ontstaan en ontwikkeling van constitutionele instituties kunnen echter maar zeer ten dele worden begrepen door kennisneming van de grondwettelijke en wettelijke bepalingen. Men kan immers de instituties van het constitutionele recht slechts begrijpen, en de constitutionele rechtsnormen slechts verstaan, als men ze relateert aan de ontwikkelingen van de samenleving en haar waardepatronen.

De Nederlandse geschiedenis had, met vallen en opstaan weliswaar, een erfelijk ambt aan het hoofd van de staat voortgebracht dat zich, in die omstandigheden haast onontwijkbaar, wederom manifesteerde toen de Franse troepen in I8I3 de Lage Landen ontruimden. In die dagen van onzekerheid kon de Nederlandse constitutionele identiteit bevestiging vinden door de zoon van de laatste stadhouder tot drager van de soevereiniteit te maken. Het koningschap, dat in I8I4/I8I5 in de Grondwet werd geregeld, institutionaliseerde een reeds aanwezige, in die zin preconstitutionele erkenning van de nazaten van Willem van Oranje, bijgenaamd Willem de Zwijger, als persoonlijke verankering van het staatsbestel en als dragers van verwachtingen omtrent het aan de constitutie ten grondslag liggende waardepatroon waarvan de herkenningspunten reeds in het leven van Willem van Oranje te vinden waren. ${ }^{17}$ Omdat dit laatste in beweging is gebleven, is het koningschap dat ook.

Die betekenis kan een erfelijk koningschap alleen verkrijgen en behouden als het zich mee-ontwikkelt in de sociaal-culturele dynamiek en juist in die veranderlijkheid constitutionele stabiliteit verschaft. De sociaal-culturele spankracht van het huis Oranje-Nassau bleek in 1830 te klein ten opzichte van de Belgen, ${ }^{18}$ maar in 1848 - in de fameus geworden ene nacht waarin Willem II zichzelf heruitvond - groot genoeg voor de vestiging van de parlementaire democratie.

De revolte van Troelstra, de inval door Nazi-Duitsland, het conflict rond Greet Hofmans en de Lockheed-affaire hadden kunnen uitlopen op een dislegitimatie van het koningschap, en in dat geval zou het meest waarschijnlijke gevolg een overgang naar de republikeinse staatsvorm zijn geweest. De jonge koningin Wilhelmina won echter de harten van zo veel burgers nadat Troelstra zich weer in het parlementaire

I7 H. Klink, Opstand, politiek en religie bij Willem van Oranje 1559-1568. Een thematische biografie (diss. Utrecht), Heerenveen: Uitgeverij Groen en Zoon 1997.

I8 Zie over de constitutionele tegenstellingen die tot de Belgische Opstand bijdroegen (waaronder het toenemend absolutisme van Willem I en het verzet van de toenmalige minister van Justitie Van Maanen tegen de Belgische verlangens naar ministeriële verantwoordelijkheid en volkssoevereiniteit): P. van Velzen, De ongekende ministeriële verantwoordelijkheid, theorie en praktijk 1813-1840 (diss. Tilburg), Nijmegen: Wolf Legal Publishers 2005, hoofdstuk 8. 
systeem en dus ook in het voortbestaan van de monarchie moest voegen. ${ }^{19}$ Anders dan de toenmalige koning der Belgen en de toenmalige koning van Italië, die door te veel gewilligheid in gewijzigde machtsverhoudingen uiteindelijk de troon verloren, plaatste de Nederlandse koningin, Wilhelmina, zich aan het hoofd van de afwijzing van de Duitse bezetting. Haar nationaal leiderschap in ballingschap tijdens de bezettingsjaren 1940-'45 was beslissend voor het behoud van de Nederlandse waardigheid als soevereine staat, maar de verwachtingen van koningin Wilhelmina van een op het koningschap steunende nationale eenheid werden al spoedig na de Bevrijding gefrustreerd: het parlementaire karakter van de Nederlandse democratie bleek vitaal en resistent. ${ }^{20}$ Ook was het koningschap te veel aan Nederland gebonden om de in 1948 nog nagestreefde Unie met Indonesië ${ }^{21}$ naderbij te brengen. Daarentegen wordt het koninklijk huis tot op de dag van vandaag ruimschoots aanvaard en gekoesterd in de Caribische delen van het Koninkrijk. De naoorlogse crises rondom Greet Hofmans en naar aanleiding van de Lockheed-affaire werden bezworen in samenspel met politici die begrepen dat grotere belangen op het spel stonden dan die van het voorval zelf - en vervolgens kaders creëerden ter voorkoming van herhaling.

Men zou dus zeer wel kunnen stellen dat er een grondwettelijke regeling omtrent het koningschap is, omdat dit van vóór de opstelling van die bepalingen tot op heden deel is blijven uitmaken van de Nederlandse geschiedenis. Dat deze geschiedenis met conflicten gepaard ging, zal niemand mogen ontkennen; soms had de afloop gemakkelijk een andere kunnen zijn en de uitkomst discontinuïteit. De politiek-historische realiteit is evenwel tot op heden dat het bestaan van het koningschap een continue factor is waaromtrent de Grondwet ordenende regels stelt.

Hiermee is het wezen van het Nederlandse koningschap uitgesproken: in continuiteit met de geschiedenis - geen predestinatie, maar wel een zinvol gebleken contingentie - heeft het ambt van een erfelijk staatshoofd zijn actuele betekenis steeds weer bevestigd. Door de bevestigende werking van het koningschap op cruciale momenten in de Nederlandse geschiedenis kon het, niettegenstaande (of liever: juist blijkens) alle veranderingen in het Nederlandse constitutionele bestel, eerst en vooral een transformationele functie vervullen. ${ }^{22}$ Hiermee doel ik op een functie die bij veranderingen een brug slaat tussen traditie en toekomst, aldus vreedzame overgangen mogelijk maakt en de legitimiteit van de Nederlandse staatsorganen bevestigt. Het koningschap kan deze functie uiteraard slechts vervullen doordat het zichzelf ook in verbondenheid met de traditie - eigen aan de erfelijkheid - op cruciale momenten herdefinieert.

I9 C. Fasseur, Wilhelmina. De jonge koningin, Amsterdam: Balans I998, pp. 559 e.v.

20 C.Fasseur, Wilhelmina. Krijgshaftig in een vormeloze jas, Amsterdam: Balans 200I, p. 495.

2I Op dat moment werd nog een Koningschap van de Unie nagestreefd. Artikel 209, derde lid, voorzag als uitkomst van de onderhandelingen een bestel waarover werd bepaald: 'De Kroon der Unie wordt gedragen door Hare Majesteit Koningin Wilhelmina, Prinses van Oranje-Nassau, en bij opvolging door Haar wettige opvolgers in de Kroon der Nederlanden.'

22 Vgl. W. Witteveen, De kabinetsformatie als machtsspel en overgangsritueel, Filosofie \& praktijk, jg. 32, nr. 2 (zomer 20II), pp. 5-I8. 
In dit preadvies wil ik de vragen die rondom het koningschap de gemoederen bezighouden, in dit perspectief plaatsen: hoe brengt de rol van de Koning in de regering, tijdens de formatie, en in de representatie van staat en samenleving continuiteit en actualiteit in harmonie? Daarbij behoort de vraag, waarop aan het slot van dit preadvies een antwoord zal worden gegeven, welke betekenis het koningschap aldus heeft voor de legitimiteit van de democratische rechtsstaat Nederland.

Niet alle vragen die rond het koningschap spelen, kunnen in dit preadvies worden behandeld. De Raad van State heeft op 23 december 20 Io voorlichting gegeven over de impact van het uitoefenen van koninklijk gezag op het privéleven van de koning en de leden van het koninklijk huis; ${ }^{23}$ aan deze analyse en aanbevelingen zal ik niet proberen iets toe of af te doen. Ook de aan het koningschap gerelateerde vragen over de omvang van het koninklijk huis, de financiële voorzieningen voor het koningschap en de verantwoordelijkheid voor de veiligheid van de koning en de leden van het koninklijk huis, hoe belangrijk ook, moeten in dit preadvies onbesproken blijven. Het preadvies beperkt zich tot de constitutionele vragen betreffende plaats en betekenis van het koningschap.

\section{I.2 Overzicht}

In dit preadvies zal zicht worden geboden op de wijze waarop het koningschap samengaat met - en als institutie mede vorm geeft aan - waarden van de eenentwingtigste-eeuwse democratische rechtsstaat Nederland. Dit impliceert dat het koningschap ook moet worden bezien in relatie tot de openheid en grensoverschrijdende verbindingen die aan dit staatsbestel eigen zijn: de internationale betrekkingen, de integratie in de Europese Unie en het principieel open staatsburgerschap.

In de tweede paragraaf van het preadvies wordt aan de hand van de geschiedenis van het koningschap de verbinding daarvan met democratische politiek geduid. De constitutionele ontwikkeling van het koningschap kon daardoor samengaan met het huidige parlementaire primaat.

De derde paragraaf gaat over de huidige betekenis van het koninklijk gezag in relatie tot politieke macht. Wat betekenen de constitutionele bepalingen omtrent de regering ('de Koning en de ministers')? Wat is de rol van de Koning in wetgeving en bestuur, en welke bij de kabinetsformatie? Wat betekent het feit dat deze leidt tot het benoemen en ontslaan van ministers bij een koninklijk besluit dat - ook waar het zijn eigen benoeming betreft - mede door de minister-president wordt ondertekend? Wat betekent het voorzitterschap van de Raad van State? Kortom: wat is de inhoudelijke betekenis ervan dat de Koning niet-politiek staatshoofd is?

De vierde paragraaf gaat allereerst in op de uitspraken die de Koning doet zonder dat publiekrechtelijke bevoegdheden worden uitgeoefend. Het daaraan eigen gezag 
blijkt van wezenlijk andere aard te zijn dan het gezag dat politieke ambtsdragers uitoefenen. Dat stelt beperkingen, maar opent ook de mogelijkheid van een voor de samenleving bindende kracht. Deze paragraaf sluit dit preadvies af met de vraag welke perspectieven voor de Nederlandse constitutionele rechtsontwikkeling worden geopend door de stabiliserende flexibiliteit van het erfelijk koningschap: de missie van een verbindend koningschap.

\section{De democratische context van het koningschap}

\section{I Van soeverein naar stadhouder, en van stadhouder naar soeverein}

De Akte van Verlatinge had een eind gemaakt aan de centraliserende innovaties van de Habsburgse soevereiniteit over de Nederlanden, althans de noordelijke. De politieke co-existentie van de 'Verenigde Nederlanden' was in hoge mate afhankelijk van de - zeer beperkte - confederale instituties. Toen Willem van Oranje op ro juli 1584 werd vermoord, werd de basis gelegd voor een erfelijk leiderschap van het geslacht Oranje-Nassau in de Republiek der Verenigde Nederlanden, ${ }^{24}$ zij het in permanente concurrentie met de stedelijke regenten. ${ }^{25}$ Deze geschiedenis vormde de grondslag voor de institutionalisering van het koningschap in I8I4/I8I5. De in Nederland aanwezige traditie - met het huis van Oranje-Nassau en de persoonlijke rol van Willem Frederik als bindende factoren - werd gekoppeld aan de systematiek van het Wener Congres, waar een beperkt aantal monarchale sleutelfiguren zichzelf tot ankerpunten van de statenordening wilde maken. ${ }^{26}$

Het Nederlandse koningschap is in de loop van twee eeuwen als koninklijk gezag meer en meer losgemaakt van de uitvoerende macht. Dat deze bij de instelling van het koningschap nog samenvielen, vloeide voort uit de toenmalige opvattingen over de Koning als persoonlijk drager van de soevereiniteit van de staat. ${ }^{27}$ Onmiddellijk na de landing van prins Willem Frederik, de zoon van de laatste erfelijke standhouder, proclameerde hij zichzelf als Souverein Vorst der Verenigde Nederlanden. Hij aanvaardde op 2 december $18 \mathrm{I}_{3}$ 'de souvereiniteit over de Vereenigde Nederlanden, ingevolge de algemeene uitgedrukte begeerte des volks' die hem door (zelfbenoemde) vertegenwoordigers van het volk was aangeboden. Onmiddellijk daarna dechargeerde hij het voorlopige 'Algemeen Bestuur der Verenigde Nederlanden' - een bewind dat zich na het vertrek van de Fransen had gemanifesteerd - en verklaarde 'dat geen voortaan te maken besluit of reglement eenige verbindende kracht

24 Vgl. A.Th. van Deursen, Maurits van Nassau. De winnaar die faalde, Amsterdam: Uitgeverij Bert Bakker 2000.

25 G-J. Leenknegt, R. Kubben en B. Jacobs, Opstand en eenwording. Een institutionele geschiedenis van het Nederlandse openbaar bestuur, Nijmegen: Wolf Legal Publishers 2006.

26 E. Weis, Der Durchbruch des Bürgertums. 1776-1847 (Propyläen Geschichte Europas, Band 4), Frankfurt am Main: Ullstein I975, p. 342.

27 Zie over de ontwikkeling van het begrip soevereiniteit in relatie tot het Nederlandse constitutionele recht C.A.J.M. Kortmann, Constitutioneel recht, Deventer: Kluwer 2008, pp. 69-72. 
hebben kan of mag, dan voor zoo verre het geëmaneerd zal zijn van ons of van door ons gestelde of bevestigde ambtenaren. ${ }^{28}$ In ditzelfde besluit kondigde de vorst aan, een constitutie aan zijn 'geliefde landgenooten' te zullen aanbieden. De soevereiniteit van de vorst werd in de woorden van deze proclamatie dus als het ware herleid tot een soevereiniteitsoverdracht door het volk - waarmee in de opvatting van velen ook een eind was gekomen aan de nog in de Staatsregeling van 1798 aangenomen volkssoevereiniteit. In overeenstemming met de na de nederlagen van Napoleon voltrokken restauratie kreeg het staatsgezag - anders dan in de tijd van de Republiek der Vereenigde Nederlanden - gedurende enkele decennia een in hoge mate aan de persoon van de vorst gebonden karakter. De soevereiniteit die Willem Frederik in I8I3 aanvaardde, was dus weliswaar persoonlijk, maar véél meer constitutioneel ingebed dan die welke in I58r met de Akte van Verlatinghe aan Philips II was ontzegd.

De omvorming van de onder leiding van de Souvereine Vorst gevormde staat van de Vereenigde Nederlanden tot het Koninkrijk der Nederlanden was een ontwikkeling van buitenaf. Op basis van het 'veroveringsrecht' besloten vertegenwoordigers van de grootmachten Groot-Brittannië, Rusland, Pruisen en Oostenrijk in een op 2r juni I8I4 gesloten kort verdrag, bekend als de Acht Artikelen van Londen, België met de nieuwe Nederlandse staat te verenigen, waarvoor de reeds bestaande grondwet van I8I4 de basis zou vormen, voorzien van een proviso over 'gelijke constitutionele rechten' en 'commerciële en andere rechten'; deze laatste toevoegingen kwamen voort uit de liberale elementen die de mogendheden ook elders nuttig achtten.

De van meet af aan moeizame staatsvorming was nog niet voltooid, toen de kortstondige terugkeer van Napoleon (de 'honderd dagen') een stroomversnelling veroorzaakte, die zeer aan het persoonlijk prestige van de vorst bijdroeg. Prins Willem Frederik proclameerde zich op I6 maart I8I5 als Koning van het Verenigd Koninkrijk der Nederlanden en ging daarom als koning Willem I de geschiedenis in. Nederlandse troepen namen onder leiding van zijn zoon Willem, later de tweede koning, op I8 juni I8I5 deel aan de slag bij Waterloo. Op 9 juni I8I5 - terwijl de strijd tegen de teruggekeerde keizer gaande was - was hij in artikel 65 van de Slotakte van het Wener Congres (een verdrag dat over de Nederlanden ging, maar waarbij deze geen partij waren) bevestigd als Koning van het nieuw gevormde Koninkrijk der Nederlanden:

'Les anciennes Provinces-Unies des Pays-Bas et les ci-devant provinces Belgiques (...) formeront (...) sous la souveraineté de S.A.R. le Prince d'Orange-Nassau, Prince souverain des Provinces-Unies, le royaume des Pays-Bas, héréditaire dans l'ordre de succession déjà établi par l'acte de constitution desdites Provinces-Unies. Le titre et

28 Enkele dagen later werd dit vastgelegd in het Souverein Besluit van den 6den december I8I3, no. 7 (Stb. I8I3, 4), houdende aanvaarding van de souvereiniteit der Vereenigde Nederlanden, door z.k.h. den heere prince van Oranje-Nassau, enz., enz., enz. 
les prérogatives de la dignité royale sont reconnus par toutes les Puissances dans la maison d'Orange.'

\subsection{Van protodemocratische naar democratische monarchie}

Een bijzonderheid van de recente Nederlandse monarchale staatsvorm - op dit moment nog geen twee eeuwen oud - is dat ze al bij het ontstaan ervan een protodemocratisch karakter droeg. De opstand tegen de Habsburgers was immers in hoge mate een beweging van de burgerij en leidde tot de vorming van een consensueel bestuurde confederale republiek. Deze geschiedenis heeft ertoe bijgedragen dat het koningschap zich relatief soepel met de negentiende-eeuwse democratisering en de twintigste-eeuwse vermaatschappelijking heeft kunnen associëren. Haar oorsprong heeft de Nederlandse monarchie van meet af aan behoed voor een autocratische ontwikkeling, die bijna alle verwante continentale monarchieën fataal is geworden.

Gedurende een korte periode - van I8I4 tot I840 - leek het Nederlandse koningschap desalniettemin een persoonlijk en autocratisch karakter aan te nemen. Het persoonlijke karakter van het nieuwe vorstelijke gezag paste meer bij sfeer en politieke strekking van het Congres van Wenen dan bij Nederland. Namens de Soevereine Vorst van de Verenigde Nederlanden trad in Wenen een afgezant op die de persoonlijke vertrouweling van de vorst was, voor zover dit uit zijn levensloop valt af te leiden, zelf geen Nederlander: Alexander von Gagern. Op 2I september I8I5 werd de soevereine vorst Willem Frederik echter ingehuldigd - niet gekroond - als Koning der Nederlanden, een ritueel verschil dat - aldus Fasseur - past bij de republikeinse oorsprong van de constitutionele positie van het huis Oranje-Nassau. ${ }^{29}$ Koning Willem I bestierde in deze periode de zaken van de staat in persoon, daarbij geholpen door zijn ministers. ${ }^{30}$ Machtenscheiding was slechts rudimentair aanwezig. Hoewel de door de Koning uitgeoefende soevereiniteit het geheel van de staatsfuncties betrof, waren de wetgevende macht en de rechtsprekende macht wel reeds in I8I5 meer van het koninklijk gezag onderscheiden. De bepaling dat 'alomme in de Nederlanden regt (wordt) gesproken in naam en van wege den Koning' (artikel I62 van de Grondwet naar de tekst van I8I5) strekte ertoe rechtspraak als staatsfunctie vast te leggen, en daarmee - in tegenstelling tot de vroegere provinciale jurisdicties - de rechtseenheid in het Koninkrijk te verzekeren. 'Het beleid der criminele justitie' werd door artikel I83 exclusief aan de provinciale hoven en de rechtbanken 'toebetrouwd' en artikel I86 garandeerde de benoeming van rechters en hoofden van de parketten voor het leven. De wetgevende macht was in artikel 105 aan Koning en Staten-Generaal gezamenlijk opgedragen, maar van de 'besluitenregering' van

29 O.c., p. I4.

30 P.J. Oud (Het jongste verleden. Parlementaire geschiedenis van Nederland. Deel I. 1918-1922, Assen: Van Gorcum, Prakke \& Prakke i968, p. I) beschreef dit als volgt: 'De koning, persoonlijk verantwoordelijk, wiens ministers niet anders dan zijn "commiezen” zijn, wenst alles te regelen naar eigen inzicht.' 
koning Willem I, die naast deze wetten ook burgers bindende regelingen in koninklijke besluiten vaststelde (algemene maatregelen van bestuur) zijn residuen tot in het recente verleden blijven bestaan. ${ }^{3 \mathrm{I}}$ Het protodemocratische stadhouderschap was in deze - korte - periode van de Nederlandse historie dus allesbehalve een democratische instelling.

In de veelomvattende en turbulente negentiende-eeuwse geschiedenis van het Nederlandse koningschap is de grondwetsherziening van I 848 - het jaar van liberale omwentelingen in vele Europese staten - cruciaal..$^{22}$ Voortbouwend op de in 1840 aanvaarde strafrechtelijke ministeriële verantwoordelijkheid werd in de Grondwet van 1848 de uitvoerende macht van de Koning ontdaan van zijn, in de geest van de Restauratie, persoonlijke karakter. Met deze grondwetsherziening is de basis gelegd voor het primaat van het parlement, dat in de daarop volgende geschiedenis stap voor stap is versterkt. Daardoor is de uitvoerende macht losgeweekt van de koninklijke soevereiniteit en ondergeschikt gemaakt aan de parlementair-politieke staatsmacht. De grondwetsherziening van 1848 vormde derhalve het startpunt van een constitutionele rechtsontwikkeling die de uitvoerende macht - thans spreken we liever van bestuur - heeft verzelfstandigd ten opzichte van het koninklijk gezag. Daarmee was het ook het beginpunt voor een transformatie van het koningschap tot een institutie die paste in een democratische constitutie.

\subsection{Koning en politiek}

In de negentiende-eeuwse Nederlandse politieke traditie, die doorwerkte tot ver in de twintigste eeuw, is het begrip volkssoevereiniteit in met het protestantisme verbonden politieke stromingen met afkeer bejegend; men bleef er een product van de Franse Revolutie in zien. Anderen vermeden begrijpelijkerwijs een polariserende discussie over concepten zonder rechtsgevolg. Geleidelijk aan verschoof de aandacht van deze 'bronnen' van soevereiniteit naar een aan het internationale recht ontleend concept van nationale soevereiniteit, die - niet aan de Koning noch aan het volk, maar aan de staat toegeschreven - gezamenlijk verdedigd dient te worden tegen indringers. Dit idee van 'nationale soevereiniteit' ging in het afgelopen decennium weer een rol spelen, toen bij velen de gedachte postvatte dat ze tegen een groeiende zeggenschap van de Europese Unie zou moeten worden verdedigd. Hoewel soevereiniteit een 'limiting concept' is, dat staten internationaal-juridisch voorrang geeft ten opzichte van een 'variety of non-state actors', ${ }^{33}$ wordt het toch als iets waardevols gezien, blijkbaar vanuit de discutabele gedachte dat daardoor democratische zeggenschap over het eigen lot van de gemeenschap verzekerd zou zijn.

3 I De toenmalige minister van Justitie, mr. J.P.H. Donner, meende nog in 2002, tegen het advies van de Raad van State in, een voordracht voor zo'n zelfstandige algemene maatregel van bestuur te kunnen doen. Zie daarover W.J.M. Voermans, Objets trouvés. Besluit DNA-onderzoek als uiting van een regressieve zelfstandige-AMvB-opvatting, RegelMaat 2003/2, pp. 78-83.

Brunnée \& Toope, o.c., p. 79. 
Wanneer men aanvaardt dat het grootse concept van de 'soevereiniteit' geen antwoord geeft op de gestelde vragen, komen gewone staatsrechtelijke vragen aan de orde, zoals die naar de verhoudingen tussen de 'soevereiniteitdragende instellingen', zoals Van der Hoeven ze noemde. ${ }^{34}$ Zulke verhoudingen worden gedefinieerd in termen van zeggenschap en verantwoordelijkheid. De ministeriële verantwoordelijkheid voor het doen en laten van de onschendbare Koning jegens het parlement is, voor zover het gaat om de uitvoerende macht (het bestuur) getransformeerd tot een verantwoordelijkheid van de ministers - gezamenlijk en individueel - voor hun eigen doen en laten en voor dat van de aan hen ondergeschikte ambtenaren. ${ }^{35}$ Ministeriële verantwoordelijkheid in relatie tot de Koning, als staatshoofd regeringshandelingen verrichtend, is daarvan niet meer te onderscheiden. Wél te onderscheiden is de ministeriële verantwoordelijkheid gerelateerd aan de Koning (en leden van het Koninklijk Huis) ter zake van gedragingen die geen bestuurlijk karakter dragen, zoals openbare optredens. Dat een minister - doorgaans de minister-president, minister van Algemene Zaken - daarop wordt aangesproken is echter relatief uitzonderlijk.

Omdat het ministerschap in zijn vertrouwens- en verantwoordingsrelatie tot het parlement een politiek ambt is, kan men de aldus ontstane verhoudingen ook beschrijven als het primaat van de politiek. ${ }^{36}$ Dat politieke primaat betreft zowel de wetgeving als het bestuur, maar wordt - wat dit laatste betreft - gemitigeerd door de eis van rechtsstatelijke onpartijdigheid en behoorlijk bestuur. Artikel 2:4, eerste lid, van de Algemene wet bestuursrecht omschrijft deze aldus: 'Het bestuursorgaan vervult zijn taak zonder vooringenomenheid.' Inderdaad mag een bestuursorgaan, hoezeer ook de leiding berust bij personen die een politiek ambt vervullen, in zijn besluitvorming niet op politieke sympathieën of antipathieën afgaan. Politiek legitimeert niet tot vriendjespolitiek of nepotisme.

Het politieke primaat is, zoals elke invloed in de staatsinstellingen, gebonden aan de eisen van de rechtsstaat: de Grondwet en de andere nationale, Europese en internationale regels, waaraan de overheid in heel haar doen en laten gebonden is. Het politieke gezichtspunt bij de te nemen besluiten moet dus samengaan met de vaste wil, besluiten te nemen die voor eenieder aanvaardbaar zouden kunnen zijn, ook al brengt het democratisch besluitvormingsproces met zich mee dat ze slechts door een meerderheid worden gedeeld. Daarom zijn wetgeving en de door Roberto Bin en Giovanni Pitruzzella onderscheiden vierde staatsfunctie, te weten die van de algemene beleidsbepaling (funzione di indirizzo politico) ${ }^{37}$ het domein waar de politiek

34 O.c., pp. $13-36$.

35 Deze geleidelijke transformatie is een interessant voorbeeld van constitutionele iterations zoals bedoeld door Seyla Benhabib.

36 Vgl. R. Nieuwenkamp, De prijs van het politiek primaat. Wederzijds vertrouwen en loyaliteit in de verhouding tussen bewindspersonen en ambtelijke top (diss. Twente), Delft: Eburon $201 \mathrm{I}$.

Diritto pubblico, Torino: G. Giappichelli Editore 2005, p. 68. 
thuis is. Artikel 45, derde lid, van de Grondwet noemt dit het algemeen regeringsbeleid; het heeft uiteraard in gemeenten, provincies en andere lichamen zijn equivalenten.

Politiek is dus niet zomaar een opvatting of ideologie, maar een bepaalde visie op het algemeen belang die in concurrentie met anders visies op het algemeen belang naar zeggenschap over de staatsfuncties van wetgeving en regeringsbeleid streeft. Het politieke karakter van democratische besluitvorming brengt legitimatie, maar alleen binnen de kaders van de constitutie. Daarom komt het erop aan, preciezer te bepalen hoe het specifiek politieke karakter van deze besluitvorming zich verhoudt tot de rechtsstatelijke eisen zoals grondrechten. Over het eigene van de politiek doen verschillende opvattingen opgeld. Bekend - en in zijn consequenties beruchtis het radicale vriend-vijand schema van Carl Schmitt. Deze ging ervan uit dat alles wat met de intensiteit van een binding van gelijkgezinden als 'vrienden' tegenover de 'vijanden' zich op machtsverwerving richtte, 'politiek' is..$^{8}$ Ook religie, moraal, economie en etniciteit (!), aldus Schmitt, kunnen zo politiek worden, al naar gelang de intensiteit van de strijd tegen de andersdenkenden. ${ }^{39}$ Thomas Bedorf constateert dat in Schmitts gedachtegang alle conflicten 'politisierbar' zijn, voor zover ze als 'antagonisme' worden toegespitst. $4^{\circ}$

Een gematigde vorm van een op tegenstellingen gebaseerde politieke filosofie is door onder anderen Chantal Mouffe ontwikkeld. Zij geeft zich er rekenschap van dat een ten einde doorgevoerd politiek antagonisme - in combinatie met fundamentalistische identiteitspolitiek - de democratie kan ondermijnen. Omdat het doel niet mag zijn de politieke tegenstander te vernietigen, ontwikkelde zij het 'agonisme' als model van democratische politiek. ${ }^{4 \mathrm{I}}$ Hiertegenover staat de opvatting van Hannah Arendt, die juist de verbinding met het gemeenschappelijk vrijheidsstreven als kenmerk ziet voor het politieke. Deze laatste opvatting verbindt zich op de meest natuurlijke wijzen met het rechtsstatelijke denken en een Ethos der Menschenrechte. ${ }^{42}$ Dit geeft immers hetgeen iedere mens eigen is - de persoonlijke waardigheid - voorrang boven dat waarmee mensen zich van elkaar onderscheiden. Ze is in het recente grote werk van Axel Honneth verder doordacht: het hart van de realisering van vrijheid in een samenleving als de onze is 'die politische Sphäre der öffentlichen Deliberation und Willensbildung', gekenmerkt door een omvattend 'wij'.43

38 'Die spezifisch politische Unterscheidung, auf welche sich die politischen Handlungen und Motive zurückführen lassen, ist die Unterscheidung von Freund und Feind.' C. Schmitt, Der Begriff des Politischen. Text von 1932 mit einem Vorwort und drie Corollarien, Berlin: Duncker \& Humblot 2009.

39 O.c., p. 35.

40 T. Bedorf, 'Das Politische und die Politik. Konturen einer Differenz', p. 2I, in: T. Bedorf en K. Röttgers (red.), Das Politische und die Politik, Frankfurt am Main: Suhrkamp 20I0, pp.13-37.

4I Bedorf, o.c., p. 23.

42 F. Böckle, Ja zum Menschen. Bausteine einer Konkreten Moral, München: Kösel I995, p. I02.

43 A. Honneth, Das Recht der Freiheit. Grundriß einer demokratischen Sittlichkeit, Frankfurt am Main: Suhrkamp 20II, p. 470-47I, p. 509. 
De vraag moet intussen wel onder ogen worden gezien, aldus Bedorf, of onder de huidige historische en 'mediale' omstandigheden zo'n op een gemeenschappelijke vrijheid gerichte politiek nog wel realiseerbaar is (O.c., pp. 36-37). Inderdaad is er een duidelijk waarneembare tendens in de massamedia, politiek eerst en vooral als conflict tussen personen en groepen weer te geven. ${ }^{44}$ Honneth noemt het risico van een 'Austrocknung der öffentlichen Sphäre der Willensbildung', doordat de gerichtheid op winst de overhand krijgt in de massamedia, terwijl de populaire vormen van communicatie niet meer onderworpen zijn aan toetsing naar professionele standaarden. 45

$\mathrm{Al}$ zal niet iedereen met een gerust hart Bedorfs vraag bevestigend beantwoorden, dat antwoord is temeer geboden nu nieuwe vormen van 'identiteitspolitiek' Chantal Mouffes vreedzaam agonisme - in Nederland soms als 'polarisatie' gepresenteerd - tot antagonisme dreigen te doen verworden. Daargelaten of politiek primair als gericht op consensus dan wel in een agonistische - niet antagonistische - zin wordt opgevat, een verabsolutering van het politieke als een tot vijand maken van de andersdenkende past niet in een democratische rechtsstaat. Jan Prij heeft dit - met een speelse verwijzing naar het tot vijand maken van degenen die consensus zoeken - aldus verwoord dat 'thee drinken' behoort tot het wezen van de politiek..$^{4}$ Zolang dit wordt onderkend, kan ook in de politiek van het begin van de eenentwintigste eeuw nog worden geput uit ideële bronnen van toewijding aan gemeenschappelijke vrijheid en wederzijds respect. Dat zal onontbeerlijk zijn om de idee van de democratische rechtsstaat wél levend te houden.

Dit betekent dat er in een democratische rechtsstaat institutioneel ruimte moet zijn voor wat niet politiek is. In een parlementaire democratie als de Nederlandse wordt van het staatshoofd verwacht dat hij geen macht uitoefent die gelijksoortig is aan politieke macht. Dat is een andere positie dan die van de in Duitsland ten tijde van de Republiek van Weimar direct gekozen, toegeruste Rijkspresident. Hij werd door Carl Schmitt en anderen als pouvoir neutre beschouwd, met eigen bevoegdheden, en vulde het gat dat door politieke instabiliteit in het functioneren van het staatsbestel werd geslagen. ${ }^{47}$ De positie van het huidige Nederlandse koningschap is, zoals in dit preadvies nader zal worden toegelicht, wezenlijk anders.

Diegenen die een antagonistische voorstelling van de politiek in praktijk brengen, kunnen een apolitiek koningschap niet 'plaatsen'. De daaruit voortkomende politisering van staatsfuncties is een opkomend getij, dat zich niet gemakkelijk laat keren: ze is immers nauw verbonden met de mediatisering van elk publiek discours. Politics, New York: Palgrave Macmillan 20II, p. 7.

45 O.c., p. 556 ; zie voorts p. 557 en p. 562.

46 Theedrinken als kern van het politieke, Filosofie \& praktijk, jg. 32, nr. 2 (zomer 20II), pp. I9-32.

47 K. Stern, Das Staatsrecht der Bundesrepublik Deutschland. Band II: Staatsorgane, Staatsfuktionen, Finanzund Haushaltsverfassung, Notstandsverfassung, München: C.H. Beck I980, pp. I96-I97. 
Omdat in deze voorstelling van zaken alles politiek wordt gemaakt, is het koningschap dat ook, en willen zij dat dit tot inhoudsloos ceremonieel wordt teruggebracht.

Daartegenover staan de stromingen die de politieke tegenspeler niet tot een vijand, of althans - wat de agonistische opvattingen betreft - niet duurzaam tot vijand maken. Zij verlangen dat het politieke wordt gerelativeerd en gestabiliseerd door het besef dat politiek altijd gericht behoort te zijn op wat mensen met elkaar verenigt en zullen mogelijkerwijs juist daarin het belang van een niet-politiek staatshoofd herkennen.

\section{$3 \quad$ Het koninklijk gezag}

\section{I Koninklijk gezag en politieke macht}

De bestendigheid van constitutionele vormen heeft sociaal-psychologisch wellicht een geruststellende werking, maar ze kan ook vertroebelend werken. In de actuele politieke discussie wordt de staatsrechtelijke positie van de Koning nog te vaak geduid vanuit het verleden, dus als een in de loop der geschiedenis afgekalfde alomvattende macht (soevereiniteit dus). Dat er toch telkens weer discussies opkomen over vermeende politieke macht, is terug te voeren op onvermogen om de staatsrechtelijke verhoudingen tussen koninklijk gezag en politieke macht, meer in het bijzonder Koning en ministers goed te duiden. In de actuele discussie wordt regelmatig erover gesproken of de Koning 'lid' moet blijven van de regering (aldus de memories van toelichting bij de initiatiefvoorstellen), of - in een iets andere woordkeus - 'in de regering moet blijven zitten', alsof de koningin ooit in de Trêveszaal of in een der paleizen met haar ministers bijeenkomt om over het regeringsbeleid te beraadslagen. Naar mijn indruk speelt daarin ook een rol dat respect voor traditie van het koningschap en de persoon van de koningin soms leiden tot nodeloze mystificaties. Wanneer een minister de vraag of een bepaalde aangelegenheid met de koningin is besproken alleen maar beantwoordt met een glimlachende verwijzing naar het geheim van Noordeinde of Huis ten Bosch, zet dit de hoorder in een argwanende mediacultuur op het verkeerde been. Een preciezer antwoord zou in zo'n geval zijn: 'U kunt ervan verzekerd zijn dat ik de koningin over een aangelegenheid die zo belangrijk is voor onze samenleving, naar behoren informeer. De koningin is er ook zeer begaan mee wat dit voor ons land betekent. Over het beleid ter zake beraadslagen en beslissen mijn collega's aanstaande vrijdag in de Trêveszaal.'

De in de voorgaande paragraaf geschetste ontkoppeling van koningschap en uitvoerende macht en inbedding van het koningschap in een democratisch politiek bestel kon zich voltrekken zonder dat de in 1848 ingrijpend herziene Grondwet daartoe werd gewijzigd. Het begrip 'macht des Konings' bleef nog tot 1983 in de Grondwet staan, maar had reeds lang zijn betekenis verloren, om plaats te maken voor nietpolitiek koninklijk gezag, gedragen door traditionele legitimiteit in de betekenis 
die Max Weber daaraan hechtte. ${ }^{4}$ Pas met de algehele grondwetsherziening van I983, werd een niet geheel geslaagde poging gedaan, deze veranderingen tekstueel enigszins te verwerken.

\subsection{De Koning in Grondwet en Statuut}

\subsubsection{Twee constitutionele documenten}

Er is dus alle reden om op dit punt zorgvuldig te werk te gaan. Daarvoor is allereerst een analyse van de constitutionele bepalingen nodig.

Zoals gezegd omvatte de algehele grondwetsherziening een poging de constitutionele veranderingen ten aanzien van het koningschap tekstueel te verwerken. Daarbij ontstonden discrepanties tussen de twee lagen van constitutionele ordening die het Nederlandse staatsbestel kenmerken: die van het Statuut voor het Koninkrijk der Nederlanden van 1954 en die van de Grondwet voor het Koninkrijk der Nederlanden. Ik richt de aandacht speciaal op de institutionele bepalingen betreffende het koningschap en de regering.

De voorbereidingen voor de algehele grondwetsherziening van I983 zijn onmiddellijk na de kleine herziening van 1963 gestart: in november van dat jaar werd bij het ministerie van Binnenlandse Zaken de afdeling grondwetszaken ingesteld, die na overleg met vijf (oud-)hoogleraren staatsrecht in 1966 een Proeve van een nieuwe grondwet presenteerde. In datzelfde jaar werd, volgend op enige politiek onrustige jaren - met naar Nederlandse begrippen omvangrijke verstoringen van de openbare orde - een nieuwe politieke partij opgericht (D'66, thans D66), die erin slaagde de politieke agenda drastisch te beïnvloeden. Zij presenteerde zich met een programma van staatkundige vernieuwingen die onder meer de positie van het staatshoofd raakten. Na advisering door de in 1967 ingestelde staatscommissie-Cals/Donner startte een zeer omvangrijk wetgevingsproces, dat ertoe leidde dat een vrijwel de gehele grondwet omvattende herziening op 17 februari 1983 in werking trad: juridisch geen nieuwe grondwet, maar een herziening van de Grondwet van I8I5; inhoudelijk geen ingrijpende wijziging, maar een partiële codificatie van de na 1848 geëvolueerde constitutionele grondpatronen; systematisch en redactioneel desalniettemin een nieuw document, vooral wat betreft het vooropstellen van de grondrechten. ${ }^{49}$

\subsubsection{Het koningschap}

De Grondwet bepaalt in de in 1983 vastgestelde tekst in artikel 24:

\footnotetext{
48 Zie M. van Ostaijen en A.C. Zijderveld, 'Koning(in) moet in regering blijven', de Volkskrant, 7 januari 2011 .

49 C.A.J.M. Kortmann, De Grondwetsherzieningen 1983 en 1987, Deventer: Kluwer 1987.
} 
'Het koningschap wordt erfelijk vervuld door de wettige opvolgers van Koning Willem I, Prins van Oranje-Nassau. ${ }^{50}$

In deze bepaling is de term 'koningschap' in de plaats gekomen voor de sinds I8I5 gebezigde woorden 'kroon der Nederlanden', welke op hun beurt de in de Grondwet van I8I4 gebezigde woorden 'Souvereiniteit der Vereenigde Nederlanden' vervingen. Als gevolg hiervan wijkt sinds 1983 de redactie van de Grondwet af van die in artikel I van het Statuut voor het Koninkrijk der Nederlanden van I954:

'De Kroon van het Koninkrijk wordt erfelijk gedragen door Hare Majesteit Juliana, Prinses van Oranje-Nassau en bij opvolging door Hare wettige opvolgers.'

Aan het verschil tussen 'Kroon' en 'koningschap' lijkt intussen geen staatsrechtelijke betekenis toe te komen. Het verschil in startpunt voor de erfopvolging (Willem I vs. Juliana) zegt wel iets: hiermee brengt het Statuut bij uitstek tot uitdrukking dat in 1954 niet de constitutionele orde van het bestaande Koninkrijk werd gewijzigd, maar 'een nieuwe rechtsorde'sז in het leven werd geroepen, met de bestaande Nederlandse constitutionele rechtsorde als belangrijkste bouwsteen. Artikel 5 van het Statuut verwijst vervolgens terug naar de Grondwet: het koningschap met de troonopvolging wordt - net als onder andere 'de koninklijke en de wetgevende macht in aangelegenheden van het Koninkrijk' - 'voor zover het Statuut hierin niet voorziet geregeld in de Grondwet voor het Koninkrijk.' Het koningschap van het semi-federale staatsverband van Nederland, Aruba, Curaçao en Sint-Maarten (eertijds: van Nederland, Suriname en de Nederlandse Antillen) bouwt dus voort op het reeds aanwezige koningschap van het Koninkrijk der Nederlanden dat eerder in de Grondwet voor het Koninkrijk der Nederlanden was geconstitueerd als Rijk in Europa met overzeese rijksdelen (eerder: koloniën).

\subsubsection{De ministers}

Minder bekend is het ook in 1848 in de Grondwet opgenomen artikel dat zei: 'De hoofden der ministeriele departementen zorgen voor de uitvoering der Grondwet en der andere wetten, voor zooverre die van de Kroon afhangt' (artikel 73, tweede lid, gevolgd door leden waarin werd bepaald dat hun verantwoordelijkheid door de wet wordt geregeld en het contraseign van koninklijke besluiten werd geregeld). Deze bepaling is bij de Grondwetsherziening van 1983 vervallen, omdat ze thans als overbodig wordt beschouwd.

Artikel 73, tweede lid, van de Grondwet, zoals in I848 herzien, liet dus wel de opdracht van de uitvoerende macht aan de Koning in artikel 54 staan, maar maakte met een pennenstreek een einde aan de situatie ten tijde van koning Willem I, die

50 Deze bepaling is de in I983 van kracht geworden herformulering van een bepaling die sinds I8I5 deel uitmaakte van de Grondwet voor het Koninkrijk der Nederlanden. De bepaling luidde van I8I5 tot I963 onveranderd: 'De kroon der Nederlanden is en blijft opgedragen aan Zijne Majesteit Willem Frederik Prins van Oranje Nassau, om door Hem en Zijne wettige nakomelingen te worden bezeten erfelijk, overeenkomstig de na te melden bepalingen.'

5 I Aldus ook het in 1948 in de Grondwet ingevoegde hoofdstuk over de 'overgang naar een nieuwe rechtsorde' en de preambule van het Statuut. 
als het ware eigenhandig de uitvoerende macht uitoefende, zoals ook zijn zoon Willem II dat aanvankelijk had gedaan. Van toen af stonden in het bestuur de ministers en de door hen geleide ministeries centraal en verplaatste, wat het beraad over het beleid betreft, het zwaartepunt zich gaandeweg van het overleg tussen de Koning en zijn ministers naar de ministerraad, d.w.z. naar personen die weliswaar door de Koning werden benoemd en ontslagen ('naar welgevallen', aldus de Grondwet van I8I5 tot I983), maar die alleen in functie konden zijn zolang ze het vertrouwen hadden van de meerderheid in het parlement. Dit betekent dat in de periode van 1848 tot $I_{9} 83$ de uitvoerende macht een politiek en bureaucratisch karakter aannam. De ministers konden en kunnen zich weliswaar zien als 'dienaren van de Kroon', maar dit dienen is dienstbaarheid aan de door de Koning gerepresenteerde res publica, geen hofhouding. Wie over het regeringsbeleid beslissen, is sinds 1983 eenduidig vastgelegd in artikel 45, derde lid, van de Grondwet: 'De Ministerraad beraadslaagt en besluit over het algemeen regeringsbeleid.'

\subsubsection{De regering voeren}

Tot op dit punt is er wel een tekstuele discrepantie, maar geen substantiële disharmonie tussen de bepalingen van het Statuut en die van de herziene Grondwet. Gecompliceerder wordt het beeld als wij de aandacht richten op artikel 2 van het Statuut. Dit bepaalt: 'De Koning voert de regering van het Koninkrijk en van elk der landen. Hij is onschendbaar, de ministers zijn verantwoordelijk.'

In deze en verscheidene andere bepalingen van het Statuut komt de Koning voor als gepersonifieerde constitutionele institutie, net als in de Grondwet zoals die tot I983 luidde, die tezamen met de Staten-Generaal de wetgevende macht uitoefent (artikel IIg Gw), die de uitvoerende macht uitoefent (artikel 56), het opperbestuur heeft van de buitenlandse betrekkingen (artikel 58), het oppergezag over de krijgsmacht (artikel 68), het opperbestuur van de algemene geldmiddelen (artikel 72), het recht van munt (artikel 73), adeldom verleent (artikel 74), het recht van gratie heeft (artikel 77), de Kamers kan ontbinden (artikel 82), ministers naar welgevallen benoemt en ontslaat (artikel 86), en bestuursgeschillen beslecht gehoord de Raad van State. De Koning personifieerde de staat in velerlei functionele gedaante, wat historisch te herleiden was uit de hem opgedragen soevereiniteit, maar inmiddels overgegaan in de officialiteit ${ }^{52}$ - het koninklijke waarmerk - van door democratisch gelegitimeerde staatsorganen, professionele bureaucratieën en bestuur en rechtspraak gegenereerde beslissingen.

\subsection{5 'De regering wordt gevormd door de Koning en de ministers'}

In I848 werd in de Grondwet ook de bepaling opgenomen die nog steeds ongewijzigd, nu als artikel 42, tweede lid, in onze Grondwet staat, namelijk 'De Koning is onschendbaar; de ministers zijn verantwoordelijk.' De grondwetsherziening van 
I983 maakte echter een eind aan de daaraan voorafgaande bepaling, luidende 'De uitvoerende magt berust bij den Koning,' en aan alle andere vergelijkbare bepalingen voor specifieke onderwerpen. In dat jaar is artikel 42, eerste lid, van de Grondwet, van kracht geworden, luidende: 'De regering wordt gevormd door de Koning en de ministers'.

De opstellers van de Proeve hadden nog gemeend een eigentijdse tekst te kunnen opstellen waarin toch de koning ${ }^{53}$ in de betekenis van 'hoofd van de regering' (aldus artikel 29, tweede lid) werd gehandhaafd, waarbij zij aantekenden: 'Overigens worden in het ontwerp en in de toelichting de termen kroon, regering en koning door elkaar gebruikt'.54 De Staatscommissie adviseerde in 197I echter anders. Waar het gaat over erfopvolging en regentschap zou het woord 'Koning' in gebruik moeten blijven, maar overigens zou op veel plaatsen naar het oordeel van de staatscommissie beter van de 'regering' of 'bij koninklijk besluit' kunnen worden gesproken. In sommige bepalingen, waaronder die over het wetgevingsproces, meende de staatscommissie echter de Koning wel te moeten vernoemen. ${ }^{55}$

De regering volgde in het in I980 ingediende wetsvoorstel de Staatscommissie op de voet, ook wat betreft de toelichting, waarin het weinig verhelderende begrip 'twee-eenheid' wordt gebruikt, naast 'eenheid van Koning en ministers' ${ }^{5}{ }^{6}$ In de memorie van toelichting bij een van de andere voorstellen tot grondwetsherziening is een algemene uiteenzetting gegeven over de nieuwe terminologie. ${ }^{57}$ Het woord 'Koning' wordt gebruikt waar deze 'persoonlijk wordt bedoeld', in andere gevallen 'bij koninklijk besluit' of 'regering', maar inzake bepaalde ambtshandelingen in het wetgevingsproces (namelijk de indiening en de bekrachtiging) wordt wél van 'de Koning' gesproken..$^{8}$ Dat neemt echter niet weg dat de Koning hier niet persoonlijk kan worden bedoeld, nog afgezien daarvan dat bij door beide Kamers aanvaarde initiatiefvoorstellen van wet het geven of weigeren van bekrachtiging een afzonderlijk besluitvormingsproces van de regering onder ministeriële verantwoordelijkheid vereist; ik kom op dit punt later terug.

Met 'Koning' zowel als 'ministers' wordt in artikel 42, eerste lid, van de Grondwet gedoeld op ambten, die uiteraard door personen worden vervuld maar niet deze personen zijn. Het hoge ambt van staatshoofd heeft geen politieke functie in het huidige Nederlandse staatsrecht, ook geen beknotte vorm daarvan, zoals vaak wordt afgeleid uit de invoering van de ministeriële verantwoordelijkheid. Dat was nog wel

53 Daar met een kleine $\mathrm{k}$ geschreven; ik volg in dit preadvies regel $\mathrm{r} 6 . \mathrm{N}$ van de leidraad in de Woordenlijst Nederlandse Taal, samengesteld door het Instituut voor Nederlandse Lexicologie in opdracht van de Nederlandse Taalunie, Tielt/Den Haag: Lannoo/Sdu Uitgevers 2005.

54 Proeve van een nieuwe grondwet, 's-Gravenhage: Staatsuitgeverij I966, p. 86.

55 Eindrapport van de Staatscommissie van advies inzake de Grondwet en de Kieswet, 's-Gravenhage: Staatsuitgeverij 1971, pp. 36-37.

56 Kamerstukken II I979/80, I6 035, nr. 3, pp. 5-6.

57 In aanvulling daarop vermeldt de toelichting in Kamerstukken II I979/80, I6 o34 (RII38), nr. 3, p. 3 nog dat de 'veelzinnige term' kroon niet meer zal worden gebruikt.

58 Kamerstukken II I977/78, I5 047 (RIo99), nr. 3, pp. 9-ı. 
zo in 1848 , ook nog enigszins in 1948 , maar de huidige constitutionele verhoudingen zijn anders. Dit betekent echter niet dat de Koning in het huidige Nederlands constitutionele recht teruggeworpen zou zijn op een inhoudsloos, zogenaamd 'ceremonieel' (in België zegt men 'protocollair') koningschap. Aan het koningschap is gezag verbonden dat niet politiek van aard is - in elk geval niet meer sinds 1956 , toen de laatste poging in die richting van koningin Juliana door het derde kabinetDrees werd afgewezen.59 Daarom hoeft de aard van de verhouding tussen Koning en ministers ook helemaal niet met omtrekkende bewegingen te worden omschreven, zoals uit reverentie of onwetendheid zo vaak geschiedt, en evenmin hoeft door grondwetswijziging een probleem te worden opgelost, dat er niet is.

De toelichting bij deze bepaling houdt in 'dat het aanbeveling verdient de eenheid van Koning en ministers op duidelijke wijze tot uitdrukking te brengen de plaats van deze twee-eenheid in ons staatsbestel nader te preciseren door daaraan, in overeenstemming met het ten onzent heersende spraakgebruik, de benaming regering te geven. ${ }^{60}$ Deze redactie is desalniettemin in het licht van de poging tot gestileerde terminologie een mogelijke bron van misverstanden gebleken. Ook hier kan niet de koning persoonlijk worden bedoeld. Omdat 'regering' wordt ervaren als een politieke institutie, lijkt de koning dan nog steeds persoonlijk een aandeel te hebben in politieke macht - ook al bestaat ter zake ministeriële verantwoordelijkheid.

Toch is de bepaling op zichzelf niet verkeerd, mits men onderkent dat hier gesproken wordt van het staatshoofd. De regering voert wel politiek in de zin van beleid, maar de regering is in een democratisch-rechtsstatelijke constitutie altijd van en voor alle burgers, dus geen werktuig van de politieke meerderheid van het moment. De 'twee-eenheid' van staatshoofd en politiek verantwoordelijke ministers brengt mee dat ministers dit tot hun verantwoordelijkheid moeten rekenen. Wanneer politici tot het ministersambt worden geroepen, betekent dit niet dat dat ambt alleen nog maar aan politieke verantwoordingsstructuren is onderworpen; die van de normen en beginselen van het recht blijven onverminderd maatgevend. Zolang ze dit in acht nemen blijft de twee-eenheid met de Koning als staatshoofd intact, inclusief het apolitieke karakter van het aandeel dat degene die het koningschap vervult, hoogstens vragend, waarschuwend en aanmoedigend kan hebben. Tot publieke ambten geroepen politici hebben - zoals Jan Prij in zijn artikel over het theedrinken als wezenskenmerk van democratische politiek duidelijk maak $\mathrm{t}^{6 \mathrm{I}}$ - een verantwoordelijkheid waarvan niemand ze kan vrijstellen, namelijk om besluiten te nemen met een inhoud die de Koning voor alle Nederlanders verbindend kan afkondigen en die daarmee de vorm van een koninklijk besluit kunnen aannemen.

\footnotetext{
59 C. Fasseur, Juliana \& Bernhard. Het verhaal van een huwelijk. De jaren 1936-1956, Amsterdam: Uitgeverij Balans 2009, p. 449.

$60 \quad$ P. $7 \mathrm{I}$.

6I Zie hierboven $\$ 2.3$.
} 
Anders gezegd: dat de regering zich manifesteert als eenheid van Koning en ministers past in het democratisch staatsbestel, gegeven de in elk geval sinds het midden van de vorige eeuw vaststaande primaire betekenis van de ministeriële verantwoordelijkheid als verantwoordelijkheid van de ministers voor hun eigen beslissingen. Dit betekent dat de ministers het regeringsbeleid bepalen en dat de Koning niet als staatshoofd in hun verantwoordelijkheid kan treden. De betekenis van de eenheid van de wisselende ministers met het staatshoofd is dat zij hun politieke zeggenschap moeten uitoefenen als constitutionele ambtsdragers die in de ministerraad of anderszins in onderlinge afstemming het regeringsbeleid bepalen.

\subsubsection{Tussenconclusies}

Ik verbind aan het vorenstaande enkele met elkaar samenhangende intermediaire conclusies:

I. De grondwetsherziening van 1983 markeerde een voltooiing van de in 1848 begonnen scheiding tussen koningschap en uitvoerende macht.

2. De grondwetsherziening van 1983 bevestigde een ontwikkeling van de in 1848 ingevoerde ministeriële verantwoordelijkheid voor van de Koning uitgaande besluiten naar - zeker na de Tweede Wereldoorlog - volledige politieke zeggenschap over het regeringsbeleid.

3. De grondwetsherziening van $\mathrm{I}_{98} 3$ bracht niet alleen een terminologische wijziging, maar ook een systematische, namelijk door invoering van 'regering' als van de persoon van de koning onderscheiden, maar wel het staatshoofd omvattende institutie. Het verhaal als zou dit een kwestie van terminologie zijn, vertroebelde echter het zicht op de institutie van het koningschap.

4. Als gevolg van een gebrek aan duidelijkheid over het koningschap als niet-politieke constitutionele institutie is er ook een gebrek aan duidelijkheid over de betekenis van de bepaling dat 'de regering wordt gevormd door de Koning en de ministers.' Een goed begrip daarvan vereist dat de ministers hun rol verstaan binnen de context van een volgroeide democratische rechtsstaat. Dat de regering wordt gevormd door Koning en ministers, betekent niet dat de Koning 'lid' is van de regering, als ware dit een college van personen die met elkaar delibereren over het regeringsbeleid.

5. Dat de ministers met het staatshoofd de regering vormen, brengt in twee richtingen verplichtingen mee. Het staatshoofd mag zich niet in de plaats stellen van de ministers bij de hun opgedragen beleidsbepaling. De ministers dienen te beseffen dat ze niet alleen maar politici zijn, maar op de eerste plaats constitutionele ambtsdragers.

6. De regering treedt naar buiten als constitutionele Koning bij koninklijk besluit op voordracht van de verantwoordelijke minister, die het besluit mede ondertekent. De ministerraad verschijnt zelf niet als besluitvormend orgaan, een enkele zeer specifieke situatie daargelaten.

7. De ministeriële verantwoordelijkheid voor het doen en laten van het staatshoofd geeft hun niet het recht, de Koning te politiseren en zijn publieke uitingen als staatshoofd ondergeschikt te maken aan hun politieke doelstellingen, die 
immers altijd onder het democratische voorbehoud vallen van de tijdelijkheid van politieke macht. Terecht wordt de Troonrede niet op voorstel van de zittende minister-president gebruikt om een voorganger bij monde van de Koning de mantel uit te vegen; dat het dezelfde Koning is die de Troonrede uitspreekt, heeft hier een disciplinerende werking in het democratisch proces.

\subsubsection{Koning en ministers in de praktijk}

Artikel 42 , eerste lid, wordt - zoals gezegd - faliekant misverstaan als de Koning wordt beschouwd als een 'lid' van de regering naast de ministers, ${ }^{6}{ }_{2}$ alsof zijn rol daarin ook maar enige gelijkenis zou kunnen vertonen met het inbrengen van beleidsmatige overwegingen die als het ware concurreren met die van de politiek ambtsdragers, de ministers en staatssecretarissen. Koninklijke besluiten komen alleen op voordacht van de betrokken minister(s) tot stand; zo ook, zij het in de vormen van het nader rapport inzake een wetsvoorstel, de koninklijke boodschappen waarmee wetsvoorstellen aan de Tweede Kamer worden aangeboden. Een klein deel van deze voordrachten wordt voorafgegaan door informatie aan de Koning en eventueel een bespreking daarvan. Dit betreft die aangelegenheden waarbij de omstandigheden van het functioneren als staatshoofd of het Koninklijk Huis zelf betrokken is, zonder dat dit kan afdoen aan de eigen verantwoordelijkheid van de minister voor de voordracht die hij doet en die tot het koninklijk besluit c.q. de indiening van het wetsvoorstel leidt. Diegenen die nu in discussies over het koningschap naar voren brengen dat 'een eind moet worden gemaakt aan de situatie dat de Koning lid is van de regering', als ware dit een bevoegdheid tot meebeslissen, trekken dus tegen een imaginaire windmolen ten strijde.

Hiermee bedoel ik meer dan dat het 'lid' zijn van de regering een onjuiste parafrase is van artikel 42 , eerste lid; ${ }^{6} 3$ die woordkeus was trouwens in het niet zo verre verleden ook nogal eens te vinden in ambtelijke stukken. De nota van minister-president Rutte van 24 mei 201 I neemt er duidelijk afstand van: 'Het zou (...) een misverstand zijn om te menen dat de term "regering" betrekking heeft op een "college" van Koning en ministers dat besluiten neemt. ${ }^{94}$ Ook de interpretatie van de regelmatige gesprekken van Koning en ministers, vooral de minister-president, als uiting van koninklijke betrokkenheid bij de uitvoerende macht gaat langs de relevante vragen heen. Die gesprekken zouden immers evengoed kunnen plaatsvinden als artikel 42, eerste lid, niet in de Grondwet staat. Ze vinden bijvoorbeeld ook in het Verenigd Koninkrijk plaats, zeer intensief zelfs, terwijl daar onder '(Her/His Majesty's) Government' een institutie wordt verstaan waarvan de Koning expliciet geen deel

\footnotetext{
62 In dit preadvies wordt de positie van de staatssecretarissen steeds geïmpliceerd in die van de ministers, in plaats van wie zij immers hun bevoegdheden uitoefenen.

63 Aldus zowel enkele passages in het PvdA-rapport ( $\$ 4$ spreekt van het 'koninklijk lidmaatschap van de regering') als passages in de memories van toelichting van de PVV-voorstellen.

64 Kamerstukken II 20Io/II, 32 79I, nr. I, p. 3.
} 
uitmaakt. ${ }^{65}$ In de beroemd geworden omschrijving van Walter Bagehot 'the sovereign has, under a constitutional monarchy such as ours, three rights: the right to be consulted, the right to encourage, the right to warn. And a king of great sense and sagacity would want no others. ${ }^{66}$ Deze omschrijving helpt om artikel 42 , eerste lid, te duiden, maar houdt een zekere ambivalentie: is dit een inhoudelijke bepaling van de contacten tussen Koning en ministers die zich kwalitatief niet onderscheidt van om het even welk goed gesprek tussen goed geïnformeerde personen, of gaat het toch om een discontinue politiek rol? Een bagatelliseren van de betekenis van gesprekken van Koning en ministers, alsof die vergelijkbaar zijn met de gesprekken met om het even wie die de minister tot andere of diepere gedachten zou kunnen brengen, doet geen recht aan de bijzondere positie van de Koning in het staatsbestel en de daaruit voor ministers voortvloeiende plicht om zulke gesprekken serieus te nemen; maar zij dienen ook te beseffen dat zij het zelf zijn die verantwoordelijkheid dragen voor de beslissingen, een verantwoordelijkheid die ze op niemand - ook niet binnenskamers, ook niet als zelfrechtvaardiging - kunnen afwentelen, al helemaal niet door wankelmoedigheid de plaats te laten innemen van respect voor het eigen ambt.

De vraag of er situaties zijn waarin de Koning mag weigeren de gevraagde ambtshandeling te verrichten is - in afwijking van de verhullende beschrijvingen die toen nog in de meeste staatsrechtelijke verhandelingen waren te vinden - al in 1973 door Van der Hoeven beantwoord. In zijn artikel over 'Modern koningschap' omschreef hij de bevoegdheid van de Koning om méér te doen dan vergeefs waarschuwen: dat is slechts het geval als het functioneren van het constitutioneel bestel in het geding is, bijvoorbeeld door een ongrondwettige machtsgreep van een minister of omstandigheden van buitenaf. ${ }^{67}$ De situaties waarin de Koning medewerking mag weigeren, zijn dus geen andere dan waarin hij die medewerking moet weigeren. Het bij meningsverschil tijdelijk neerleggen van het koninklijk gezag is dus naar Nederlands constitutioneel recht nimmer zinvol.

Ik meen dan ook dat noch een duiding van een gedachtewisseling tussen Koning en ministers als (geruststellend) futiel, noch een duiding daarvan als (ongewenst) politiek, recht doet aan de constitutionele aard daarvan. Om te beginnen is de rol van de Koning als staatshoofd bij de totstandkoming van wetsvoorstellen, wetten en koninklijke besluiten helemaal niet van politiek-inhoudelijke aard. De tussenkomst van de Koning bij de meest gewichtige ambtshandelingen van de overheid en de vorm van het koninklijk besluit betekent dat de Koning als staatshoofd de geldigheid

65 L. Prakke, Het Verenigd Koninkrijk van Groot-Brittannië en Noord-Ierland, pp. 895-896, in: L. Prakke en C.A.J.M. Kortmann (red.), Het staatsrecht van landen van de Europese Unie, Deventer: Kluwer 2009, pp. 877-950.

66 W. Bagehot, The English Constitution, Ithaca, New York: Cornell University Press I963 (oorspronkelijke editie I867), p. III.

67 J. van der Hoeven, 'Modern koningschap', p. 444, in: Socialisme en democratie ro (I973), pp. 44I447; ook in: Staatsrecht en bestuursrecht, Opstellen van Mr. J. van der Hoeven, Zwolle: W.E.J. Tjeenk Willink I984, pp. I0I-I07 (zie p. I04). 
van de handeling tot uitdrukking brengt. Daar waar de Koning ambtsdragers, in het bijzonder ministers en staatssecretarissen ontmoet, kunnen in beslotenheid - op hoofdpunten, en onvermijdelijk in verhouding tot het geheel van het beleid slechts in zeer beperkte mate - vragen van beleid en goed bestuur aan de orde komen.

De zwijgzaamheid die daarover wordt betracht, is nodig omdat anders de ministeriële verantwoordelijkheid zou worden doorbroken. Geheimzinnigheid kan echter ook ertoe leiden dat er andere dingen worden vermoed dan reëel zijn. Noch voor de Koning, noch voor een minister die zijn ambt serieus neemt, kán zo'n gesprek betekenen dat daar een derde forum van verantwoording ontstaat. Een minister verantwoordt zich uitsluitend aan de Kamer, voor de rechter (in geval van beroep tegen overheidsbesluiten of in extreme situaties strafrechtelijk) en persoonlijk in geweten. De Koning vertegenwoordigt als staatshoofd het niet-politieke gezichtspunt en mag een minister hoogstens aanspreken op de basisprincipes van democratischrechtsstatelijk bestuur zoals de betrouwbaarheid van de overheid en de integere afwikkeling van de beslissingen die met een koninklijke toespraak - bijvoorbeeld de Troonrede - of ambtshandeling aan de burgers kenbaar worden gemaakt. Daarmee blijven het beslissingen waarvoor de ministers exclusief verantwoordelijk zijn.

\subsubsection{De plaats van het koningschap in het huidige constitutionele recht}

In de Grondwet moet al naar gelang de strekking van de bepaling onder 'Koning' hetzij de tot het koningschap geroepen persoon, dan wel het staatshoofd worden verstaan. De terminologie is dus minder simpel en gestileerd dan de memorie van toelichting anno 1978 wilde doen geloven. De bepaling dat de regering wordt gevormd door de Koning en de ministers moet worden verstaan binnen de actuele constitutionele verhoudingen. Daarin betekent ze dat de politieke besluitvorming van de ministers haar constitutioneel rechtmatige gedaante krijgt in officiële handelingen van het staatshoofd, die geen andere kunnen zijn dan die waarvoor ministers verantwoordelijkheid dragen en die op hun voordracht tot stand komen. Het hieraan ten grondslag liggende beleid kan onderwerp van bespreking zijn tussen Koning en ministers, zonder dat dit afdoet aan grondwetsbepalingen volgens welke de raad van ministers beraadslaagt en besluit over het algemeen regeringsbeleid en die de totstandkoming van koninklijke besluiten binden aan een voordracht door de ministers en hun exclusieve verantwoordelijkheid voor de inhoud daarvan.

De begin september 2oII door de PVV-leden Elissen en Helder aanhangig gemaakte initiatiefvoorstellen zijn, aldus de memories van toelichting, gericht op 'een modernisering van de rol van de Koning in ons staatsbestel. Daarbij wordt beoogd de Koning een representatieve en ceremoniële rol als staatshoofd toe te kennen.' Gesteld wordt dat de Koning een invloed uitoefent binnen de regering, die niet met 'een moderne democratie' verenigbaar zou zijn; de remedie zou zijn een plaatsing van de Koning buiten de staatsrechtelijke besluitvormingsstructuren. 
Voor zo'n wijziging van de grondwetsbepalingen bestaat naar mijn oordeel geen goede grond; voor zover men invloed van de Koning ziet en wil bestrijden, kan ze deze ook helemaal niet beletten. Dat de Koning ingevolge artikel 42, eerste lid, van de Grondwet geen politieke rol heeft, volgt enerzijds uit de wijze waarop het constitutionele ambt als staatshoofd is bepaald - namelijk niet als regeringsleider: dat is de minister-president - en anderzijds uit de bepaling in artikel 45, derde lid, dat de ministerraad beraadslaagt en besluit over het algemeen regeringsbeleid en eenheid van het beleid van de afzonderlijke ministers bevordert.

Een voorstel tot wijziging van de Grondwet zou niet in strijd mogen komen met artikel 2, eerste lid, eerste volzin, van het Statuut voor het Koninkrijk der Nederlanden: 'De Koning voert de regering van het Koninkrijk en van elk der landen.' Een rijkswet tot wijziging van het Statuut behoort dan ook tot de vanuit de PVV-fractie aanhangig gemaakte initiatiefvoorstellen; daarvoor is voorafgaande aanvaarding bij landsverordening door Aruba, Curaçao en Sint-Maarten vereist. Daarbij zou onder ogen moeten worden gezien dat de beperking van het koningschap tot 'een representatieve en ceremoniële rol' in de Caribische delen van het Koninkrijk analoog zou kunnen worden toegepast op de Gouverneur, die immers de Koning vertegenwoordigt - en daarmee een van de weinige barrières tegen de soms reeds aanwezige overpolitisering zou slechten.

\subsection{De kabinetsformatie}

Naast de besluitvorming over het regeringsbeleid is het vooral de kabinetsformatie waarop zich de discussie over de plaats van de Koning in het constitutioneel bestel concentreert. Ook hier is de achtergrond gelegen in de historische relatie tussen Koning en ministers. Voor een beschrijving van het formatieproces biedt dit preadvies geen ruimte; verwezen zij naar de hand- en leerboeken staatsrecht en naar de recente Parlementaire geschiedenis van Nederland van de hand van Jac Bosmans en Alexander van Kessel, die zich tot en met de vorming van het kabinet-Rutte uitstrekt. ${ }^{68}$

Van 1815 tot 1983 bepaalde de Grondwet - behoudens kleine redactionele wijzigingen onveranderlijk - dat de Koning de ministers (hoofden der ministeriële departementen) benoemt en ontslaat 'naar welgevallen'. In de eerste decennia van het Koninkrijk gaven deze woorden adequaat de relatie tussen Koning en ministers aan. Hierbij dient welgevallen overigens niet te worden opgevat als constitutioneel gewettigde humeurigheid. Met 'welgevallen' (evenals thans nog 'pleasure' in het Britse publiekrecht: to be detained during Her Majesty's pleasure is hechtenis voor onbepaalde tijd) werd gedoeld op het discretionaire, niet nader genormeerde karakter van een bevoegdheid. Na de overgangsperiode I840-I848 werd de koninklijke bevoegdheid tot het benoemen en ontslaan van ministers steeds meer bepaald door 
de ministeriële verantwoordelijkheid en de daarop geënte vertrouwensrelatie met het parlement. Wat begon als een noodzaak voor de door de Koning samengestelde kabinetten om vertrouwen te zoeken bij de meerderheid in het parlement (het zogenoemde dualisme van regering en parlement), had zich in 1939 ontwikkeld tot een verplichting van de Koning om zich vooraf ervan te vergewissen dat de politieke en personele samenstelling van het kabinet aan de vertrouwensregel beantwoordt.

In deze lange periode van I848 tot 1939 zijn enkele parlementair-historische markeringspunten aanwijsbaar. De gebeurtenissen in de jaren zestig van de negentiende eeuw leidden tot een beperking van het ontbindingsrecht, d.w.z. van de bevoegdheid van de Kroon om na een conflict met de Kamer tot Kamerontbinding over te gaan en aldus bij de kiezers steun te zoeken voor het doorregeren. 'In I866', aldus Bosmans en Van Kessel, 'treedt de minister van Koloniën P. Mijer plotseling af om zich even later te laten benoemen tot gouverneur-generaal van Nederlands-Indië. ${ }^{\prime 69}$ De motie waarin dit werd afgekeurd leidde niet tot aftreden van het kabinet, zoals nu het geval zou zijn, maar tot Kamerontbinding. Hetzelfde kabinet kwam in verband met de Luxemburgse kwestie een jaar later weer in conflict met de Kamer, maar de Koning weigerde de ministers het gevraagde ontslag en ging opnieuw tot Kamerontbinding over. Na de verkiezingen sprak de Kamer uit 'dat geen landsbelang de jongste ontbinding der kamer vorderde'. Het kabinet hield het desalniettemin nog een jaar vol, maar legt in I868 na een hernieuwd conflict met de Kamermeerderheid het loodje. Sindsdien is aangenomen dat een kabinet niet meer dan eenmaal via Kamerontbinding bij de kiezers zijn gelijk kon proberen te halen. Deze ontwikkeling relativeerde de dualistische legitimatie die kabinetten nog aan de benoeming door de Koning ontleenden.

In de verdere geschiedenis is de dualistische legitimatie verder afgezwakt en uiteindelijk geheel verdwenen. Sinds 1933 heeft geen conflictontbinding van de Kamer meer plaatsgevonden. Afgezien van de kabinetten in oorlogstijd, die in Londen zonder parlement met de Koningin de regering in ballingschap vormden - werd in 1939 voor het laatst een kabinet gevormd dat meende een zelfstandige legitimatie aan de benoeming door de Koningin te kunnen ontlenen. In een door de kwestie-Oss aangetast politiek klimaat was in 1939 het vierde kabinet-Colijn gebroken door onenigheid over de door minister-president Colijn gewenste bezuinigingen, met name in verhouding tot het beleid van de RKSP-minister van Sociale Zaken, mr. C.P.M. Romme. ${ }^{70}$ Toen Colijn vervolgens een formatieopdracht van de Koningin meende te kunnen uitvoeren zonder zich te vergewissen van voldoende steun in de Kamer, werd het kabinet bij zijn eerste optreden in de Kamer geconfronteerd met een motie van

69 Zie E. van Raalte, Het Nederlandse Parlement, 's-Gravenhage: Staatsuitgeverij I966, p. 72; de ontbinding van 1958 , door Van Raalte in dit verband ook behandeld, leek alleen uiterlijk nog op de vroegere conflictontbindingen, maar was in feite een voorbeeld van de daarna vaker toegepaste methode om via verkiezingen een situatie te creëren waarin een nieuwe coalitie kon worden gevormd.

70 Zie P.J. Oud, Het jongste verleden. Parlementaire geschiedenis van Nederland. Deel V. 1937-1940, Assen: Van Gorcum; Prakke \& Prakke I968, p. II3. 
afkeuring wegens de wijze waarop het tot stand was gekomen. Deze motie, voorgesteld door de RKSP-fractievoorzitter Dekker, luidde: 'De Kamer, overwegende, dat de Kabinetsformatie niet heeft geleid tot het optreden van een Kabinet, dat de noodige waarborgen biedt voor een deugdelijke behartiging van 's Lands belang in gemeen overleg met de Staten-Generaal, keurt het optreden van dit Kabinet af en gaat over tot de orde van den dag.' Daarop trad het vijfde kabinet-Colijn af, met een zittingsduur van twee weken en twee dagen het kortst zittende uit de Nederlandse parlementaire geschiedenis. ${ }^{71}$

Hiermee is komen vast te staan dat de Koning niet los van het parlement het aantreden van een kabinet kan legitimeren; zonder grondwetswijziging was de constitutie op een cruciaal punt veranderd, hetgeen in 1983 werd bevestigd met het schrappen van de woorden 'naar welgevallen' omdat - aldus de memorie van toelichting deze 'woorden niet passen bij de bestaande situatie, dat een minister of staatssecretaris die het vertrouwen van een parlementaire meerderheid mist, niet kan aanblijven. ${ }^{72}$ Anno I980 wilde de regering blijkbaar nog niet met zoveel woorden uitspreken dat ook het aantreden van ministers afhankelijk is van het vertrouwen van het parlement.

Geconstateerd kan worden dat na de Tweede Wereldoorlog de Koningin zich steeds, alvorens een kabinet te benoemen ervan heeft vergewist, dat dit in overeenstemming was met de wens van de Kamermeerderheid. Hetzelfde geldt voor kabinetten met een beperkt mandaat, zoals kabinetten die tot taak hebben nieuwe verkiezingen voor te bereiden. Indien het om een gewoon kabinet gaat, blijkt dit steeds uit het regeerakkoord; gaat het om een (romp)kabinet dat na een kabinetscrisis demissionair nieuwe verkiezingen voorbereidt, een interim-kabinet met beperkt mandaat (zoals het kabinet-Zijlstra in I966-I967), of om een kabinet zonder vaste meerderheid, dan geldt evengoed dat de benoeming c.q. de ontslagweigering door de Koningin zal moeten worden gedragen door een vooraf geconstateerd parlementair mandaat. In (in)formatieopdrachten pleegt dit te worden omschreven als het 'kunnen rekenen op een vruchtbare samenwerking met de Staten-Generaal'.

Sinds de Tweede Wereldoorlog heeft de Koningin zich daarvan vergewist in gesprekken die zij of de door haar aangewezen informateur - zo nodig per fase in de formatie - met de (betrokken) fractievoorzitters voert. De Koningin raadpleegt daarbij ook de vaste adviseurs in het formatieproces, te weten de beide Kamervoorzitters en de vice-president van de Raad van State. Naar ik meen is de verificatie of een Kamermeerderheid het mandaat van het kabinet droeg, in één geval achterwege gebleven. Dit deed zich voor in 2002, toen het tweede kabinet-Kok in afwachting van de vorming van een nieuw kabinet na de reeds uitgeschreven verkiezingen zijn ontslag aanbood wegens het rapport over Srebrenica, maar - zonder dat de Kamermeerderheid zich over dit voornemen had doen kennen - demissionair aanbleef.73

$7 \mathrm{I} \quad$ O.c., pp. $133-\mathrm{I} 58$.

72 Kamerstukken II I979/80, I6 035, nr. 3, p. 6.

73 Mijn bijdrage aan de Prakke-bundel; mijn Formatieseizoen. 
De Koning is wel degene die ministers benoemt en ontslaat, besluiten die in zoverre verschillen van andere koninklijke besluiten dat de ministeriële verantwoordelijkheid op het moment van benoeming een Münchhausen-achtige constructie vergt. Tot 1983 was het gebruikelijk dat het contraseign van de benoeming van de nieuwe minister-president werd gegeven door een minister die van het oude naar het nieuwe kabinet overgaat (hetgeen echter niet onder alle omstandigheden mogelijk is), sindsdien bepaalt de Grondwet dat de nieuwe minister-president de verantwoordelijkheid voor zijn eigen benoeming door medeondertekening van het koninklijk besluit strekkend tot zijn benoeming neemt. Dit brengt mee dat de Koning als staatshoofd het vaste element is in de transitie van het oude, demissionaire kabinet, dat onmogelijke de vorming van een nieuw kabinet tot zijn taak kan rekenen, naar het nieuw aantredende kabinet. Dit geeft de taak van het staatshoofd een bijzonder karakter, waarop ik nu nader zal ingaan.

Al enige decennia wordt de vraag gesteld of de totstandkoming van een kabinet anders kan worden geregeld. Minister-president Rutte schreef in zijn brief van 24 mei 201 I dat dit onderwerp losstaat van wat de Grondwet over de regering bepaalt. ${ }^{74}$ Historisch is dat niet juist, want-zoals de Grondwet het tot 1983 omschreef-waren het de door de Koning benoemde ministers die - aldus artikel 86, derde lid, van de Grondwet naar de tekst van 1963 - zorgden 'voor de uitvoering der Grondwet en der andere wetten, voor zoverre die van de Kroon afhangt.' In het verlengde hiervan was het aan de Koning te voorzien in de regering door ministers te benoemen die het vertrouwen van het parlement genieten.

Deze leidende rol van de Koning in het formatieproces werd echter, zoals wij zagen, door de aanvaarding van het parlementaire primaat in de formatie teruggebracht tot een zorg voor het formatieproces en ontdaan van preferenties die voor de oorlog nog van de Koning in politieke zin konden uitgaan. Daarmee was overigens het dualisme van regering en parlement niet ten einde, maar kreeg het een andere betekenis. De Tweede Kamer ontwikkelde zich meer en meer tot de actieve controleur van het kabinet, hetgeen - vaak in weerwil van de politieke regie in coalities en hun gedetailleerde regeerakkoorden - werd voorgesteld als een nieuw dualisme. In het democratiebegrip zoals zich dat in het laatste kwart van de twintigste eeuw - onder meer blijkens een groeiende belangstelling voor parlementaire onderzoeken - ging ontwikkelen, werd accountability verbonden aan scheiding van verantwoordelijkheden; dit geldt ook voor het dualisme dat op gemeentelijk en provinciaal niveau doelbewust is ingevoerd. Het parlementaire primaat ten opzichte van het kabinet kreeg vanaf de jaren zeventig een merkwaardige vertaling in een nieuwe (beweerdelijk constitutionele) gedragsnorm volgens welke na een kabinetscrisis Kamerontbinding en nieuwe verkiezingen moeten volgen. Een systematische of politieke noodzaak voor de aanvaarding van deze nieuwe norm was er inderdaad niet, althans niet wanneer het zou gaan om één nieuwe formatie in dezelfde kamerperiode; drie - de 
vorming van het kabinet-Zijlstra in dezelfde periode als waarin de kabinetten-Marijnen en -Cals waren aangetreden en afgetreden - was inderdaad teveel.

Deze ontwikkeling van het parlementaire stelsel bevestigde in elk geval dat vanuit de Kamer bezien de leden van het kabinet steeds minder 's Konings ministers waren, en steeds meer die van de Kamermeerderheid. In deze gedachtegang is een kabinetscrisis als het ware een Kamermeerderheidscrisis, met als gevolg dat zich pas na een kiezersuitspraak weer een handelingsbekwame nieuwe Kamermeerderheid kan manifesteren. Dit verklaart de praktijk van de verplichte Kamerontbinding na een kabinetscrisis, alsook de sinds de beginjaren van de eenentwintigste eeuw steeds vaker gestelde plicht van een kabinet, moties uit te voeren.

In het verlengde van het breed en intens geclaimde politieke primaat van de Kamer ten opzichte van het aan haar verantwoordelijke kabinet, liet zij echter na, in de kabinetsformatie het initiatief naar zich toe te trekken. Nadat de voorstellen van de meerderheid in de staatscommissie-Cals/Donner voor de verkiezing van de kabinetsformateur waren gesneuveld, aanvaardde de Kamer wel op 2 maart 197I, acht weken voor de Kamerverkiezingen, een motie over de procedure van de kabinetsformatie, voorgesteld door het KVP-Kamerlid Kolfschoten. Volgens deze motie zou de Kamer via een meerderheidsuitspraak over de te benoemen formateur in een openbaar proces zelf de leiding in het formatieproces nemen, maar-zoals gezegd ondanks de aanneming van deze motie en latere bevestigingen daarvan, deed ze dit nimmer. Op 20 april 2010 - vlak voor de verkiezingen van dat jaar - werd op voorstel van de leden Van der Ham en Van Gent in het Reglement van Orde van de Tweede Kamer een bepaling opgenomen die een actievere opstelling van de Kamer mogelijk maakte:

'Artikel 139a. Debat over verkiezingsuitslag en kabinetsformatie

I. In de eerste vergadering na haar verkiezing kan de Kamer beraadslagen om de betekenis van de verkiezingsuitslag vast te stellen en zo richting te geven aan de kabinetsformatie.

2. De Voorzitter overlegt voorafgaand aan het debat met de beoogde fractievoorzitters over de wenselijkheid van de beraadslaging en, indien die er is, over de procedure van het debat.

3. Na afronding van elke tussenfase in een kabinetsformatie kan de Kamer beraadslagen over de richting van een nieuwe formatie- of informatieronde.

4. Na een tussentijdse val van het kabinet kan de Kamer beraadslagen over de wenselijkheid of richting van een nieuwe kabinets(in)formatie. ${ }^{75}$

Dat de Kamer ook in 2010 weliswaar enkele malen met de informateurs debatteerde, maar geen richtinggevende uitspraken deed, is verklaarbaar uit het kiesstelsel: in een parlement met uitsluitend minderheidsfracties heeft de Kamermeerderheid niet 
vanzelf een politiek leiderschap; daarin verschilt Nederland van bijvoorbeeld GrootBrittannië met zijn (tot voor kort effectieve) meerderheidsstelsel bij verkiezingen. Pas als er een kabinet is gevormd (en soms ook dan nog niet) kan zich via de coalitie zoiets als de politieke leiding van de Kamermeerderheid manifesteren.

Daardoor bleef de Koning genoodzaakt als staatshoofd de regie te voeren over de formatieprocedure, een regie die - zoals gezegd - niet programma en samenstelling van het kabinet betreft, maar op een stabiele vertrouwensrelatie met het parlement is gericht. Dat is vaak een complex proces, dat soms extra wordt belemmerd door allerlei ferme uitspraken tijdens de voorafgaande verkiezingscampagnes, zoals verzekeringen dat over bepaalde onderwerpen niet zal worden onderhandeld en op de persoon gerichte diskwalificaties.

Thans stellen PvdA en PVV voor de Tweede Kamer te belasten met de regie over de kabinetsformatie. Het PvdA-rapport bepleit een wijziging van het Reglement van Orde, blijkbaar vanuit de verwachting dat de Kamer zichzelf aldus zal kunnen dwingen te doen wat zij sinds de aanneming van de motie-Kolfschoten heeft nagelaten. Acht dagen na de verkiezingen, na informeel overleg en beëdiging van de leden, zou de meerderheid moeten uitspreken wat de 'gewenste coalitie' is en bij motie de daarbij behorende formateur moeten benoemen; bij gebrek aan overeenstemming tussen fracties die samen een meerderheid zouden vormen, zou de voorzitter van de grootste fractie formateur moeten worden. De PVV-fractie wenst een vergelijkbare regeling en heeft dit uitgewerkt in een grondwettelijke regeling, waarvan de kern is vervat in het voorstelde nieuwe artikel 42, tweede lid, van de Grondwet: 'De Tweede Kamer der Staten-Generaal formuleert ten behoeve van de vorming van een regering een informatieopdracht of formatieopdracht, en wijst voor de uitvoering daarvan een of meer informateurs, onderscheidenlijk formateurs, aan.'

In geen van beide voorstellen wordt de vraag gesteld hoe het te verklaren is dat de motie-Kolfschoten veertig jaar lang zonder belangrijke gevolgen bleef. De verklaring is eenvoudig: in ons op evenredige vertegenwoordiging gebaseerde kiesstelsel is er geen meerderheid in de Kamer met een politiek meerderheidsleider. De onderhandelingen om een meerderheid te vormen, zijn het werk van de (in)formateur. De voorstellen van PvdA en PVV verlangen echter in feite een omkering van de volgorde. De vraag moet dus worden gesteld of en hoe die omkering van de volgorde mogelijk is, en wat er moet gebeuren als de (in)formateur niet slaagt in zijn opdracht en er ook geen meerderheid kan worden gevormd voor een andere (in)formateur. Zowel een termijnbepaling als een subsidiaire procedure ontbreekt. Het zal dus van de zetelverhoudingen en het politieke klimaat na verkiezingen afhangen of vlot daarna een meerderheid zich zal manifesteren die in staat is een formateur aan te wijzen.

De vraag is dan ook of de complexiteit van het formatieproces met zo'n ogenschijnlijk simpel voorstel kan worden beantwoord. De voorstellen voorzien niet in enig mechanisme om uit impasses te komen, terwijl die toch bij een noodzaak tot coalitievorming waarschijnlijk zijn. De leidende politici hebben de neiging om 
tussenfasen in de formatie tactisch te benutten en de veelheid van gissingen over diepere bedoelingen hebben in de hand gewerkt dat de koninklijke regie over het proces soms op achterdocht stuit. In feite volgt deze echter een strak patroon, met een aantal onuitgesproken, maar uit het feitelijk verloop van kabinetsformaties af te leiden preferenties die in elk geval tot 2010 breed werden gedeeld:

- een parlementair kabinet dat berust op een akkoord tussen fracties waarvan geestverwanten tot het kabinet toetreden, geniet de voorkeur boven andersoortige kabinetten;

- nadat het politieke veld in kaart is gebracht (vaak de taak van de eerste informateur) is de grootste fractie - eventueel na het werk van een louter terreinverkennende informateur - als eerste geroepen in de persoon van een geestverwant die als informateur optreedt, een meerderheid voor zo'n kabinet tot stand te brengen;

- een programmatisch homogene, brede meerderheid heeft de voorkeur boven wankele combinaties.

Deze impliciete normatieve uitgangspunten zullen in een empirische studie van het verloop van kabinetsformaties in de afgelopen vijftig jaar kunnen worden geverifieerd en gepreciseerd. De meest controversiële formatieprocessen in deze periode waren die van 1972-I973, I977 en 2010. In 1972-I973 kwam uiteindelijk een kabinet tot stand dat min of meer aan deze uitgangspunten beantwoordt, maar was de weg daarheen extreem lang en gecompliceerd doordat PvdA, D'66 en PPR een regeerakkoord hadden gesloten over de inhoud waarvan zij niet wilden onderhandelen, maar waarvoor zij geen meerderheid hadden verkregen. In 1977 kwam een kabinet tot stand onder leiding van de op een na grootste fractie, maar pas nadat uitentreuren was geprobeerd door onderhandelingen een kabinet met de grootste fractie als regeringspartij tot stand te brengen. In 20Io waren nog niet alle mogelijkheden voor een meerderheidskabinet - eventueel, zoals door de informateur Tjeenk Willink gesuggereerd, met een vrijere verhouding tot de Kamerfracties - onderzocht toen (de voorzitters van) drie fracties besloten een minderheidskabinet van twee hunner met gedoogsteun van de derde tot stand te brengen en verdere besprekingen over alternatieven af te wijzen. Dit besluit week af van de opdracht die - conform het bovenvermelde preferentieschema - aan de informateur, minister van staat Lubbers was gegeven, maar geconfronteerd met deze voorkeur van een Kamermeerderheid (althans een gestelde meerderheid, want een van de betrokken fracties was hierover verdeeld) zag deze geen andere mogelijkheid dan de Koningin te adviseren een vervolgopdracht conform deze voorkeur te geven..$^{76}$

Geconcludeerd kan worden dat in de huidige constitutionele verhoudingen de rol van het staatshoofd bij de kabinetsformatie - in weerwil van wat op basis van selectieve waarnemingen nogal eens wordt gesteld - niet politiek van aard is, maar erop gericht volgens een bestendig preferentieschema de uit minderheidsfracties

76 Vgl. Bosmans en Van Kessel, o.c., p. 247; Jaarverslag Raad van State 2010, www.raadvanstate.nl/ publicaties/jaarverslagen/, pp. 32-38. 
bestaande nieuwe kamer te geleiden naar de vorming van een parlementaire meerderheid. Als de Kamer dit niet zou wensen, zou zij kunnen besluiten, zelf na onderlinge besprekingen een (in)formateur te selecteren, met de aan hem of haar te geven taakomschrijving, zodat de Koning alleen nog de opdracht behoeft te formaliseren. Daarvoor is echter wel nodig dat de Kamer al in een vroeg stadium tot enigerlei meerderheidsvorming weet te komen. Of aldus alsnog aan de motie-Kolfschoten uitvoering wordt gegeven, zal dus van de toekomstige politieke verhoudingen afhangen dan wel van het lot van de onlangs gepresenteerde voorstellen.

\subsection{Andere grondwettelijke elementen van het koninklijk gezag}

Zoals gezegd bleek de poging om bij de grondwetsherziening een terminologie door te voeren, waarbij met 'Koning' de persoon van de koning wordt bedoeld (hetgeen niet hetzelfde is als de koning privé), en in andere gevallen een depersonaliserende uitdrukking wordt gebezigd ('bij koninklijk besluit'), niet over de hele linie vol te houden. In de artikelen 29, tweede lid, 30, eerste lid, 80, 82, 83, 84, 87, I05, I37, I38 en 139 wordt 'de Koning' genoemd als actor in het wetgevingsproces; de toelichting op de terminologie vermeldt dit ook. Daarbij gaat het steeds om ambtshandelingen van de Koning die het regeringsaandeel in het wetgevingsproces tot uitdrukking brengen. Deze bepalingen moeten dus worden gelezen in relatie tot artikel 8r: 'De vaststelling van wetten geschiedt door de regering en de Staten-Generaal gezamenlijk.' De in de zojuist opgesomde artikelen bedoelde ambtshandelingen van de Koning vinden dus, net als gewone koninklijke besluiten, onder ministeriële verantwoordelijkheid plaats. Deze ministeriële verantwoordelijkheid betreft in de verhoudingen die in de loop van de vorige eeuw vaste praktijk zijn geworden niet langer de beslissingen van een ander - de Koning - maar de eigen beslissingen van de ministers en de hun ondergeschikte, in mandaat handelende ambtenaren. In al deze bepalingen had de nieuwe terminologie van de grondwetsherziening zonder enig betekenisverschil het woord 'regering' kunnen bezigen; waar sprake is van indiening van een wetsvoorstel 'door of vanwege de Koning', volstaat 'door de regering'. Er is echter geen enkel probleem aan verbonden dat dit niet is geschied, behalve dan dat de half-geslaagde poging tot terminologische modernisering het misverstand in de hand zou werken als zou aan de Koning een persoonlijk aandeel in de regering toekomen.

Dit alles relativeert de poging om in de herziene Grondwet het woord Koning niet meer te gebruiken ter aanduiding van de regering (ook 'de Kroon') aanzienlijk. Zou men de grondwetsbepalingen over het wetgevingsproces anders hebben geredigeerd dan nog zou artikel 47 ('Alle wetten en koninklijke besluiten worden door de Koning en door één of meer ministers of staatssecretarissen ondertekend') zijn betekenis hebben behouden, aangezien het staatshoofd - onder ministeriële verantwoordelijkheid - deze ambtshandeling in persoon verricht.

Er zijn echter nog enkele grondwetsbepalingen waarin van 'de Koning' wordt gesproken, zonder dat hij uitsluitend in persoon wordt bedoeld. Interessant is 
artikel 65 , de bepaling over de troonrede, luidende: 'Jaarlijks op de derde dinsdag van september of op een bij de wet te bepalen eerder tijdstip wordt door of namens de Koning in een verenigde vergadering van de Staten-Generaal een uiteenzetting van het door de regering te voeren beleid gegeven.' Degene die in de Ridderzaal spreekt, is de Koning als staatshoofd, onder verantwoordelijkheid van de ministers, die daar zwijgen en luisteren naar een hun bekend in de oren klinkende tekst. Als bijvoorbeeld in geval van ziekte van de koning de troonrede door iemand anders wordt uitgesproken, dan geschiedt dat nog steeds namens de regering en dus, overeenkomstig de Grondwet, namens de Koning als staatshoofd, niet namens de persoon die het koningschap vervult.

De artikelen I25, I26 en I3 I betreffen de commissaris van de Koning in de provincie. Deze benaming van een ambt duidt niet op een functie die wordt vervuld in opdracht van de koning in persoon, maar in opdracht van de regering. Toch is het alleszins wenselijk in de benaming van dit ambt het accent te leggen op de afvaardiging door het staatshoofd, omdat de commissaris nu eenmaal in de provincie als eigenstandig provinciaal orgaan, tevens voorzitter van Provinciale Staten en van Gedeputeerde Staten, niet een politieke zetbaas van het kabinet is. In die zin is de commissaris niet alleen met de regering, maar ook met het staatshoofd verbonden.

Ten slotte de bepaling over de Koning als voorzitter van de Raad van State. Men zou kunnen menen dat het met de terminologie van de algehele grondwetsherziening in overeenstemming is, hier de koning in persoon aan te wijzen. Het zou echter niet in de constitutionele verhoudingen van de Nederlandse democratie passen, als de koning in persoon leiding zou geven aan het werk van de Raad van State. Dat was al zo vóór de ingrijpende herziening van de Wet op de Raad van State bij wet van I september 2010.77 (Deze wetswijziging is blijkens de memories van toelichting aan de aandacht ontsnapt van de indieners van de PVV-voorstellen.) Thans draagt de Wet op de Raad van State de advisering over wetsvoorstellen, ontwerpen van algemene maatregelen van bestuur en de goedkeuring en opzegging van verdragen op aan de Afdeling advisering, waarvan de vice-president voorzitter is, zoals de rechtsprekende taken al sinds 1976 aan een andere afdeling met een eigen voorzitter waren opgedragen.

De gedachtegang in het rapport van de PvdA-commissie - op dit ene punt overeenstemmend met de PVV-voorstellen - dat de Koning wegens zijn 'lidmaatschap'78 van de regering niet ook bij de advisering 'aan zichzelf' betrokken zou moeten zijn, berust reeds daarom op een misverstand. Echter, ook afgezien daarvan gaat dit rapport uit van een onjuiste identificatie van het werk van de Raad van State met de positie van het staatshoofd. De Afdeling advisering brengt, net als tot I september 2010 de Raad, deze adviezen uit aan de Koning, namens wie ze ook worden gevraagd. Hier is het de Koning in de betekenis van de regering die advies vraagt en krijgt.

77 www.raadvanstate.nl/over_de_raad_van_state/wet_op_de_raad_van_state/.

78 Aldus $\$ 4$ van het rapport. 
Het is evident onzinnig en onmogelijk dat de regering de Raad van State zou voorzitten. De tijd dat de koning dit in persoon kon doen is voorbij, behalve bij ceremoniële gelegenheden, laatstelijk de installatie van prinses Máxima toen zij naast de Prins van Oranje zitting kreeg in de Raad (en thans ook de Afdeling advisering) zonder daarvan lid te zijn. Het is de vice-president die de Raad van State voorzit, terwijl de zetel van de voorzitter symbolisch blijft staan, en evenzeer symbolisch leeg blijft, en die dit college naar binnen en naar buiten vertegenwoordigt.

De betekenis van het voorzitterschap van de Koning is in de huidige constitutionele verhoudingen een andere (waaraan het ceremonieel uiting geeft), namelijk dat de Raad van State als hoog college van staat niet aan een van de staatsmachten zoals de regering is gerelateerd, maar aan het staatshoofd is gelieerd. Het opdragen van het voorzitterschap van de Raad aan een benoemde functionaris - zoals thans de vice-president - zou betekenisloos zijn uit het oogpunt van beperking van politieke macht van de Koning (want die kán helemaal niet aan een ceremonieel voorzitterschap worden ontleend) maar kan wel een negatieve symboolwaarde hebben ten aanzien van de positie van de Raad van State en de wijze waarop de regering zich tot zijn adviezen behoort te verhouden. De symbolische waarde van de rechtstreekse band met het staatshoofd is immers dat regering en parlement de Raad niet behoren te zien als een van de vele adviesorganen die vanuit de zijlinie van het politieke proces commentaar geven. De Raad van State heeft een functie in het verzekeren van de constitutionele betrouwbaarheid van de vervulling van de wetgevende staatsfunctie. Daarom geldt een algemene maatregel van bestuur, waarover de Afdeling advisering van de Raad van State dient te adviseren in een advies dat met de reactie van verantwoordelijke minister(s) openbaar moet worden gemaakt, als een met extra waarborgen omgeven vorm van gedelegeerde wetgeving.

In de verhoudingen binnen het semifederale staatsverband van het Koninkrijk der Nederlanden heeft de advisering door de Raad van State van het Koninkrijk (de Raad van State aangevuld met de voor Aruba, Curaçao en Sint-Maarten benoemde staatsraden) een objectiverende en in die zin voor de autonomie van de landen van het Koninkrijk waarborgende functie; ook daaraan zou op het niveau van de constitutionele symboliek afbreuk worden gedaan als de Raad primair zou verschijnen als een gewoon Nederlands, door de regering benoemd adviesorgaan. Dit luistert temeer nauw nu in het constitutionele recht van het Koninkrijk in bijzondere omstandigheden bij een rechtstreeks op het Statuut gebaseerde algemene maatregel van rijksbestuur in de autonomie van de landen kan worden ingegrepen.

Volgens artikel 74, eerste lid, van de Grondwet en artikel I, tweede lid, van de Wet op de Raad van State heeft de Prins van Oranje, zodra hij meerderjarig is, zitting in de Raad, evenals andere leden van het Koninklijk Huis ingevolge een op artikel I, derde lid, van de Wet op de Raad van State gebaseerd koninklijk besluit. Dit betreft thans alleen prinses Máxima. Voor hen is dit een bron van kennis en inzicht; zij onthouden zich volstrekt van beïnvloeding van de inhoud van de advisering. 


\subsection{Conclusies}

I. Beschouwingen over het koninklijk gezag beginnen gewoonlijk met de historie ervan. Prins Willem Frederik aanvaardde in $\mathrm{I}_{8} \mathrm{I}_{3}$ - nog vooraleer er een grondwet was - de soevereiniteit 'ingevolge de algemeene uitgedrukte begeerte des volks'. De restauratie van de Europese monarchieën leidde in Nederland tot een gewijzigde rol van het huis van Oranje-Nassau. In de Republiek der Vereenigde Nederlanden bekleedden leden van dit huis erfelijk het ambt van stadhouder in opdracht van de soevereine Staten van de provincies; nu werden de nazaten van de laatste stadhouder dragers van de originaire staatsmacht, maar geen absolute macht, want van meet af aan was deze ingekaderd in een constitutie met grondrechten, volksvertegenwoordiging en rechtspraak.

2. Waar de Grondwet spreekt over de Koning als institutie, wordt het staatshoofd bedoeld; waar de Grondwet spreekt over de aanwijzing van de persoon die het koningschap vervult, heeft het woord Koning een persoon-identificerende betekenis. Daarnaast zijn er, in weerwil van de bij de algehele grondwetsherziening nagestreefde terminologische vereenvoudiging, bepalingen waarin - net als in vele bepalingen van het Statuut voor het Koninkrijk der Nederlanden - met de Koning de regering wordt bedoeld.

3. Hoewel het denkbaar is, het onderscheid tussen Koning als staatshoofd en Koning als regering terminologisch consequent door te voeren, moet het nut van zo'n operatie sterk worden betwijfeld. Meer last wordt veroorzaakt door de miskenning van het feit dat met de Koning in een aantal grondwetsbepalingen niet de het koningschap vervullende persoon wordt bedoeld, maar het staatshoofd. Deze misvatting speelt een rol in de in deze paragraaf besproken scheve en onjuiste voorstellingen van zaken, zoals de gedachte dat de koning persoonlijke politieke opvattingen zou inbrengen als 'lid' van de regering, of dat zou doen door manipulatie van het formatieproces, dan wel als representant van de regering, de Raad van State voorzittend, invloed zou uitoefenen op de advisering over de wetsvoorstellen van het eigen kabinet.

4. Het koninklijk gezag is het gezag van het staatshoofd. Het is geen politieke factor, maar een politiek mogelijk makende factor. We moeten ophouden het koningschap op te vatten als aftreksel van wat het heeft opgehouden te zijn, namelijk soevereiniteit in de betekenis van opperste staatsmacht, sinds de ministeriële verantwoordelijkheid volledig werd.

5. De regering wordt in die zin door Koning en ministers 'gevormd', dat zij zich manifesteert hetzij in ambtshandelingen van het staatshoofd op voordracht van en onder verantwoordelijkheid van de minister(s), hetzij in ambtshandelingen van een minister (waarbij, zoals in $\S 3.2 .7$ vermeld, onder minister mede de staatssecretaris kan worden verstaan). 


\section{Constitutionele perspectieven}

\section{I De Koning spreekt}

De waarde van het koningschap is daarin gelegen dat het staatshoofd, zich baserend op apolitiek gezag, het mogelijk maakt dat ministers bij wijze van spreken komen en gaan, terwijl de regering dezelfde blijft: niet in politieke, maar in constitutionele zin. Ook in de bekrachtiging van wetten en het nemen van koninklijke besluiten is de continuïteit in het koningschap van betekenis; veranderingen in beleid worden mogelijk gemaakt als legitieme uitdrukking van het parlementair-democratisch systeem. Het koningschap is dus de stabiele constitutionele verankering die transities mogelijk maakt, waaronder die bij een kabinetsformatie.

Deze functie van het koningschap vereist een welhaast permanente presentie in de publieke communicatie. De koningin ondertekent niet alleen koninklijke besluiten, zij spreekt, zij ontvangt, bezoekt en ontmoet medemensen, en zij heeft kinderen en kleinkinderen. De daarbij ondervonden druk op de privésfeer volgt uit de medialogica; ik verwijs hier naar de eerder genoemde nuchtere beschrijving door de Raad van State van de potentieel meest delicate processen - namelijk rond de privacy van de leden van het Koninklijk Huis.

Van andere aard dan de particuliere communicatie zijn de situaties dat de Koning spreekt, niet in privésituaties, maar als staatshoofd. Daarvoor geldt ministeriële verantwoordelijkheid, maar niet uit het oog mag worden verloren dat het hier gaat om verantwoordelijkheid die het staatshoofd de vereiste ruimte geeft; de ministeriële verantwoordelijkheid zou worden misverstaan en misbruikt wanneer ze het doen en laten van het staatshoofd zou politiseren.

Het 'programma' van het staatshoofd heeft een inhoud die - met inachtneming van de betrekkelijkheid van ieders rol in de geschiedenis - kan worden omschreven als de historische missie om de bindende factor in Nederland en het Koninkrijk der Nederlanden te zijn. Wanneer, zoals de erfelijkheid van het koningschap impliceert, dit aan de leden van een huis (het huis Oranje-Nassau) wordt opgedragen, betekent dit dat de erfgenaam de ruimte behoort te hebben zichzelf in verhouding tot die missie te definiëren. Die ruimte wordt beperkt maar ook mogelijk gemaakt door de ministeriële verantwoordelijkheid: de ministers, de minister van Algemene Zaken in het bijzonder, zal kenbaar moeten maken wanneer het koninklijk spreken zou interfereren met dat wat aan de politiek, de rechtspraak of de vrijheid van de burgers is gelaten. In dat geval zal de Koning bij ontstentenis van de bereidheid om verantwoordelijkheid te nemen, zich van spreken moeten onthouden, maar de minister zal van zijn kant niet een situatie mogen doen ontstaan waarin de Koning over deze grenzen heen tot zwijgen wordt gebracht.

De kersttoespraken van de koningin zijn een goed voorbeeld van de vrijheid van spreken die het staatshoofd toekomt. Het is niet de regering, maar de Koning, het 
staatshoofd, die met Kerstmis spreekt..9 Een vraag die naar aanleiding van opmerkingen van Huub Oosterhuis aan het licht kwam, betrof de ministeriële verantwoordelijkheid ten aanzien van de kersttoespraak van de koningin. Heeft deze verantwoordelijkheid haar de ruimte verschaft om zich naar volle overtuiging uit te spreken zonder te treden in het politieke discours? Of werd zij in een positie gebracht waarin zij zich niet meer kon uiten in haar rol van staatshoofd op het traditioneel betekenisvolle moment van het vigilie van Kerstmis? De daarover aan de minister-president, minister van Algemene Zaken, gestelde vragen konden door hem alleen in abstracte zin worden beantwoord, maar uit het feit dat de koningin met Kerstmis niet heeft gezwegen - het enige alternatief voor het houden van een toespraak die aan haar overtuigingen als staatshoofd voldoet - kan worden afgeleid dat de constitutionele grenzen over en weer zijn gerespecteerd. ${ }^{80}$

Meermalen is geconstateerd dat de toespraken van de huidige en de vorige koningin worden gekenmerkt door empathie ten opzichte van kwetsbare burgers, door acceptatie van de religieuze en culturele verscheidenheid, en door Europese en internationale verbondenheid. Dat spoort met de basisoriëntaties in de historie van het huis van Oranje-Nassau en verklaart niet alleen de teneur van deze toespraken, maar is ook een (zinvol rituele) herbevestiging van de reden waarom het koningschap in Nederland niet zomaar aan een Europees vorstenhuis is opgedragen, maar juist aan dit huis, en - naar mag worden aangenomen - ook zou ophouden te bestaan als door enigerlei calamiteit geen erfopvolging in dit huis meer mogelijk is. Minstens zo belangrijk - in feite daarmee samenhangend - is dat deze teneur spoort met de basisoriëntaties van de Nederlandse constitutie, in het bijzonder de plaats daarin van de grondrechten op gelijke behandeling, vrijheid van meningsuiting en vrijheid van godsdienst en levensovertuiging, een principieel open staatsburgerschap en de bevordering van de internationale rechtsorde.

Deze oriëntaties zijn geen stilstaand water. Een staatsrechtelijk preadvies is niet het geschikte kader voor een analyse van de kersttoespraken in de loop der jaren, maar ik meen te zien dat ze in hun ontwikkeling een significante bijdrage hebben geleverd aan een continu transformatieproces in de verhouding van ethische en religieuze waarden en maatschappelijke veranderingen.

\subsection{Koning en Constitutie}

Voor het onderwerp van dit preadvies is het van belang gebleken, te verduidelijken waarom 'het politieke' niet alles omvat wat de overheid doet. De geschiedenis heeft ertoe geleid dat het koningschap, hoewel niet als democratische institutie ontstaan,

79 Zie C. van Baalen et al. (red.), Koningin Beatrix aan het woord. 25 jaar troonredes, officiële redevoeringen en kersttoespraken, Den Haag: Sdu Uitgevers 2005.

8o Vragen van het lid Van Gent (GroenLinks) aan de minister-president, de minister van Algemene Zaken, over de uitspraken van theoloog en dichter Huub Oosterhuis over de inhoud van de kersttoespraak van H.M. de Koningin (ingezonden 23 februari 20II), Kamerstukken II 20Io/II, nr. I637. 
zich toch met democratie en rechtsstaat heeft kunnen verbinden. Als gevolg van de antagonistische politisering van de publieke zaak, staat ook het koningschap onder druk. Die druk raakt de fundamenten van ons staatsbestel in feite meer dan het klassieke, door strikt verlichtingsdenken gevoede republicanisme. De aard ervan laat zien waaruit ze voortkomt. Enerzijds zijn er degenen die het Koninklijk Huis een eenzijdige sociaal-culturele identificatie willen opleggen (zoals enkele bestuurders van Oranjeverenigingen die in 2007 tekeer gingen over een toespraak van prinses Máxima), anderzijds zijn er degenen die het koningschap al hebben losgelaten en het in de hoek willen zetten van hun politieke vijanden.

In het actuele Nederlandse 'debat' over het koningschap wordt gepleit voor een 'ceremonieel koningschap', dat in Stand.nl-achtige discussies wordt geplaatst tegenover een 'politiek koningschap'. Dit debat wordt sterk vertroebeld door twee factoren:

- De duiding wat het koningschap inhoudt, wordt in hoge mate bepaald door een historische voorstelling van koningen als opulente alleenheersers, waarvan het huidige koninklijk gezag een zwak, maar nog steeds met argusogen te volgen aftreksel zou zijn.

- Een door de osmose van politiek en massacommunicatie gegrepen beeld van democratie als allesbepalende strijd tussen tegenstanders, waarnaast in het staatsbestel geen ruimte is voor andersoortige vormen van discours dan het politieke. Zo wordt de onafhankelijkheid van rechtspraak meer gewantrouwd naarmate zij het karakter van rechtsvorming aanneemt; in reactie daarop klinkt het verlangen dat de rechters zich houden aan de 'oorspronkelijke betekenis' van wetten.

Uit het voorgaande blijkt dat we geen van beide wensen, en ons geen van beide moeten wensen. Een staatshoofd dat niet langer het constitutionele ankerpunt van de staatsinstellingen is, maar alleen 'linten doorknipt', wordt beperkt in dat wat een contemporaine invulling van het 'koninklijk gezag' (dit zijn de woorden van de Grondwet) kan zijn, namelijk een specifieke vorm van het ambt van niet-politiek staatshoofd. De Europese Unie mist zo'n bindende functie van een niet-politiek 'hoofd' dat de gemeenschappelijke basiswaarden kan vertolken.

In vergelijking met een niet-politiek presidentschap heeft het koningschap enkele belangrijke pre's: het kan steunen op een door de familiegeschiedenis van het huis Oranje-Nassau herkenbare (maar uiteraard altijd weer 'waar te maken') verbondenheid met land en volk; het berust op een levenslange bereidheid van leden van dit huis, hun actieve bestaan daaraan dienstbaar te maken; en het staatshoofd hoeft niet - zoals een president die wordt gekozen uit de rijen van de gerespecteerde expolitici - te beginnen met te bewijzen dat hij of zij de politieke betrokkenheid achter zich heeft gelaten.

Het erfelijke koningschap kent ook specifieke risico's: alleen zolang persoonlijke kwaliteiten en gedrag van de dragers van de Kroon in voldoende mate aan de normatieve verwachtingen beantwoorden, zal het koningschap langs de lijnen der 
troonopvolging kunnen worden doorgegeven. Als de koning buiten staat is tot uitoefening van het koninklijk gezag, geldt de regeling van de artikelen 35 en 36 van de Grondwet. Deze regeling is geschreven voor zeer ernstige fysieke of psychische gezondheidsproblemen. Daarbuiten is de enige situatie waarin andere staatsinstellingen de troonopvolging kunnen beletten, de voor het aangaan van een huwelijk vereiste toestemming van de Staten-Generaal.

De recente verlangens tot wijziging van de grondwetsbepalingen over de samenstelling van de regering en over de Raad van State berusten naar mijn inzicht dus niet op een deugdelijk constitutioneel begrip van het koningschap. Men kan op zijn best zeggen dat ze - behoudens het verbruik van tijd en energie van regering en parlement - niet per se schadelijke gevolgen zullen hebben: tenslotte is de positie van het staatshoofd in het Verenigd Koninkrijk ook zonder dat de Koning deel uitmaakt van de regering volop verzekerd en zijn er verschillende landen waarin de Raad van State een eigen president heeft. Naar mijn ervaring echter hebben politiek spraakmakende discussies over irreële problemen en onwerkzame oplossingen wel degelijk een schadelijk effect. Juist omdat ze reële problemen niet dichter bij een oplossing brengen, werken ze een verdere desillusie over de werking van de democratie in de hand - en daarmee precies dat antagonisme waar het koningschap tegenwicht tegen kan bieden.

De Nederlandse staatstheorie is toe aan een heroverdenking van de fundamentele concepten van democratie en politiek. Ze zou zich daarbij kunnen laven aan de discussie in Frankrijk, een land dat in veel opzichten met vergelijkbare vragen en spanningsvelden te maken heeft. In het bijzonder zal het daarbij moeten gaan om de verschillende vormen van besluitvorming over, uitvoering van en verantwoording voor recht en beleid. De kunst zal zijn te laten zien, dat een niet-antagonistisch politiek discours en een niet-misantropische massacommunicatie wél dienstbaar kunnen zijn aan transparantie en vertrouwen.

\subsection{De missie van een verbindend koningschap}

Tegen deze achtergrond kan ter afsluiting een korte omschrijving worden gegeven van de betekenis van het koningschap in de eenentwintigste eeuw. Het koningschap is van betekenis om de samenleving ontwrichtend onbegrip en vijandbeeldvorming te compenseren in verbindende functies. Het is het referentiepunt bij veranderingen zoals politieke machtswisselingen en een voortgaande Europese integratie.

De verbindende functies van het koningschap betreffen:

- de quasifederale structuur van het Koninkrijk der Nederlanden;

- de politieke pluriformiteit in verhouding tot de ideële pluriformiteit van de maatschappij, dus de eenheid van staat en samenleving;

- de wisseling van functionarissen, inclusief de eigen wisseling in het koningschap, met gebruikmaking van symbolen, rituelen en officialiteit; 
- de verhouding van de Nederlandse staat tot de Europese en internationale omgeving.

In verhouding tot deze missie van het koningschap is er ook een missie van de andere soevereiniteitdragende instellingen. Parlement en ministers zullen duidelijk moeten maken dat zij hun politieke verantwoordelijkheid binnen de democratische rechtsstaat Nederland nemen. Zij zullen moeten durven uit te spreken dat het koningschap - als apolitieke institutie - hen in staat stelt politiek te zijn, zonder de democratie op te offeren aan niet langer overbrugbare tegenstellingen.

Bij alle vergelijkingen die te pas en te onpas met de geschiedenis van de republiek van Weimar worden gemaakt, of die zeer wel kunnen worden gemaakt met de Franse Vierde Republiek en met de huidige toestand van de Unie in de Verenigde Staten, is er in elk geval één duurzame les, namelijk dat een slechts op vijandschap gebaseerde politiek zonder wederzijds respectvolle erkenning van gezamenlijkheid in chaos eindigt. Daaraan weerstand te bieden is een verantwoordelijkheid van democratische politici, juristen, journalisten, wetenschapsmensen en andere staatsburgers. Het verbindend vermogen van koningschap dat geen politieke machtsfactor wil zijn, is daarin ook een factor, naast de andere krachten die weerstand kunnen bieden aan destructieve vijandschap. Het is maar een daarvan, maar het is er wel een. 